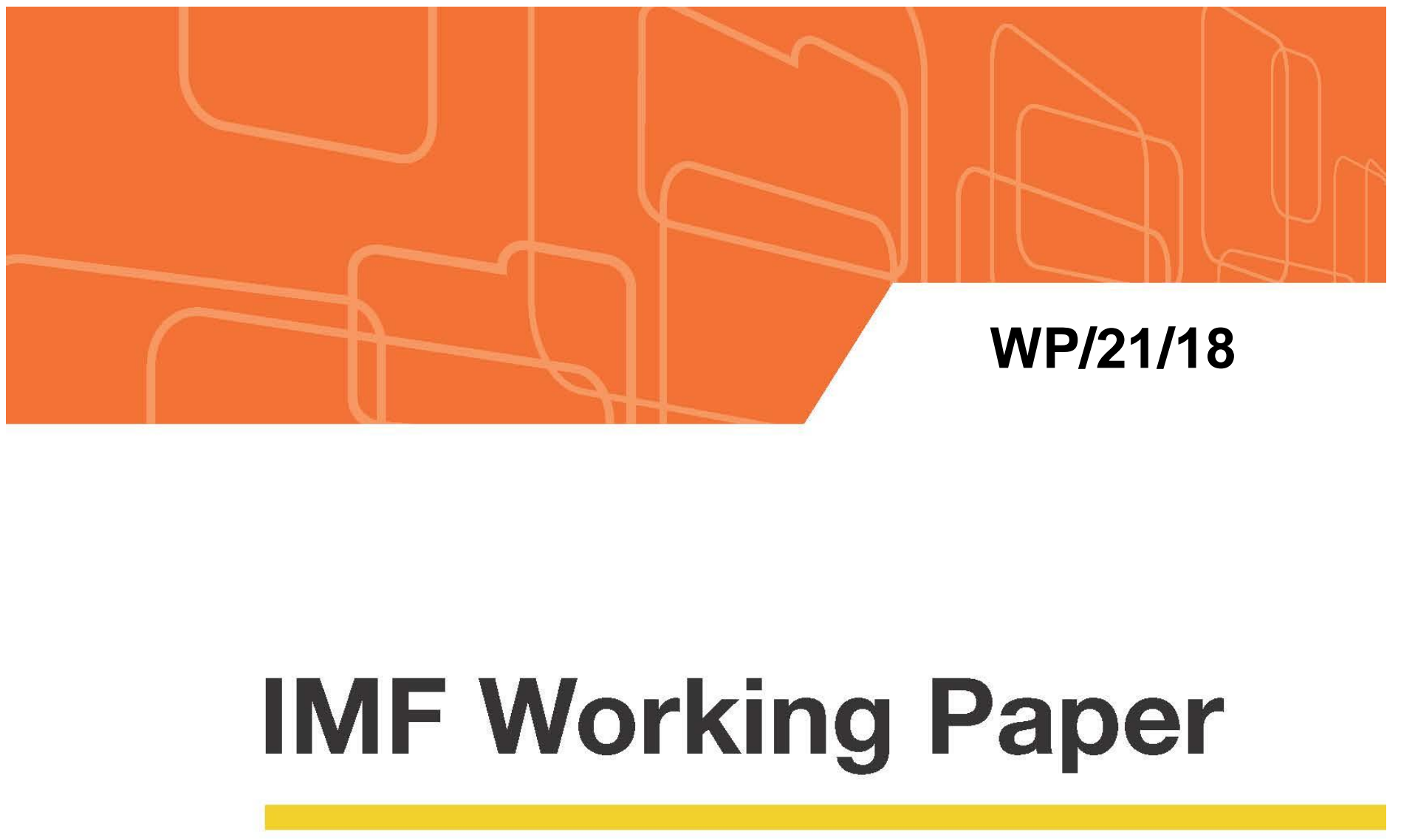

\title{
Initial Output Losses from the Covid-19 Pandemic: Robust Determinants
}

by Davide Furceri, Michael Ganslmeier, Jonathan D. Ostry, and Naihan Yang

IMF Working Papers describe research in progress by the author(s) and are published to elicit comments and to encourage debate. The views expressed in IMF Working Papers are those of the author(s) and do not necessarily represent the views of the IMF, its Executive Board, or IMF management.

$$
\text { I N T ER N A T I O N A L M O N E T A R Y F U N D }
$$




\title{
IMF Working Paper
}

Asia and Pacific Department

\section{Initial Output Losses from the Covid-19 Pandemic: Robust Determinants}

Prepared by Davide Furceri, Michael Ganslmeier, Jonathan D. Ostry, and Naihan Yang

Authorized for distribution by Jonathan D. Ostry

January 2021

IMF Working Papers describe research in progress by the author(s) and are published to elicit comments and to encourage debate. The views expressed in IMF Working Papers are those of the author(s) and do not necessarily represent the views of the IMF, its Executive Board, or IMF management.

\begin{abstract}
While the COVID-19 pandemic is affecting all countries, output losses vary considerably across countries. We provide a first analysis of robust determinants of observed initial output losses using model-averaging techniques-Weighted Average Least Squares and Bayesian Model Averaging. The results suggest that countries that experienced larger output losses are those with lower GDP per capita, more stringent containment measures, higher deaths per capita, higher tourism dependence, more liberalized financial markets, higher pre-crisis growth, lower fiscal stimulus, higher ethnic and religious fractionalization and more democratic regimes. With respect to the first factor, lower resilience of poorer countries reflects the higher economic costs of containment measures and deaths in such countries and less effective fiscal and monetary policy stimulus.

JEL Classification Numbers: E02; G01.
\end{abstract}

Keywords: COVID-19; Recession; Resilience; WALS; BMA; Model-Averaging.

Author's E-Mail Address: DFurceri@imf.org; michael.ganslmeier@spi.ox.ac.uk; JOstry@imf.org; NYang@imf.org 


\section{Table of Contents}

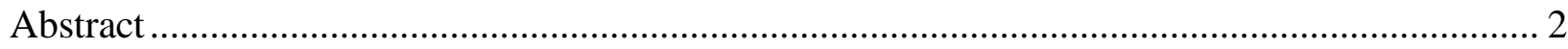

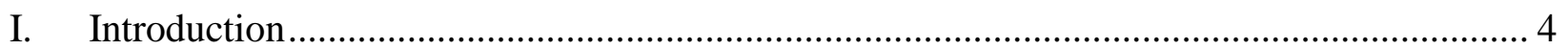

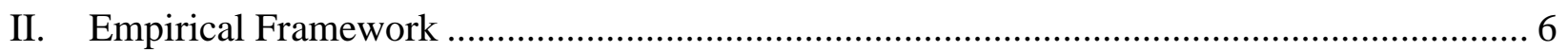

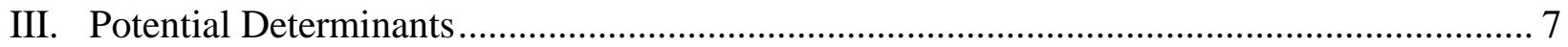

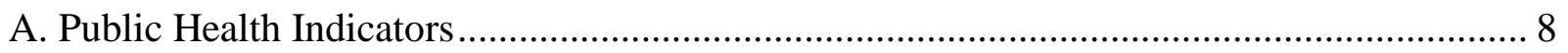

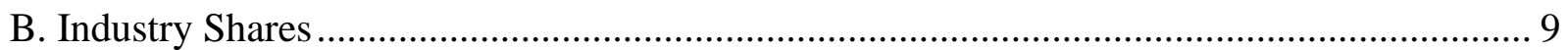

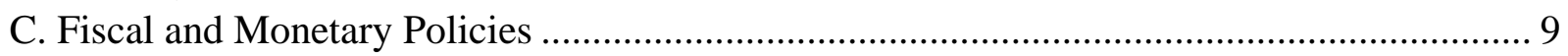

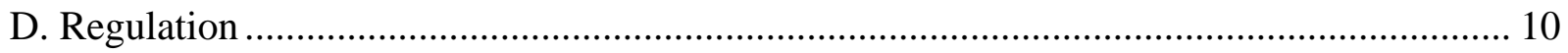

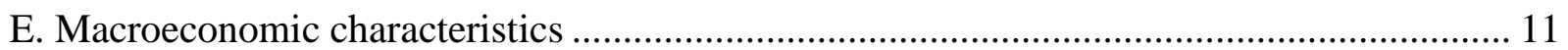

F. Development level, Demographics and Institutions …………......................................... 12

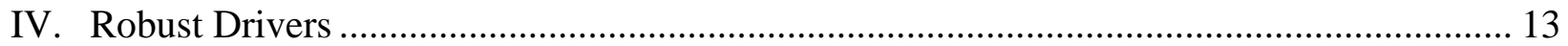

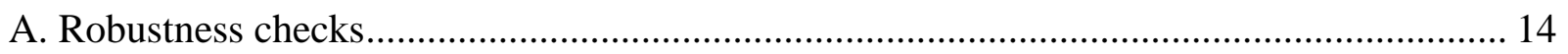

B. Cross-Country Heterogeneity: Mediating Channels …………………………................... 16

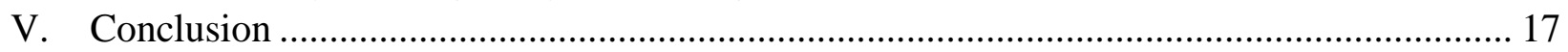

Figures

Figure 1. Distribution of Output performances (\%) - Density Plots ............................................ 23

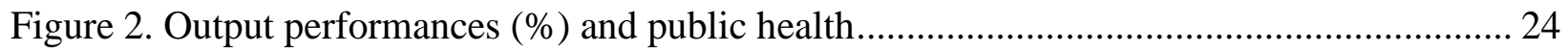

Figure 3. Output performances (\%) and sectoral composition ..................................................... 24

Figure 4. Output performances $(\%)$ and fiscal and monetary response ........................................ 25

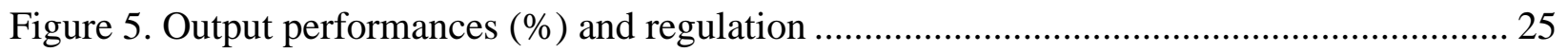

Figure 6. Output performances (\%) and macroeconomics characteristics ................................... 26

Figure 7. Output performances (\%) and development, demographic and institutions ................. 27

Figure 8. Robust drivers of output performance across countries, magnitude of the effects ....... 28

Tables

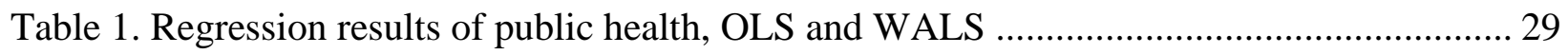

Table 2. Regression results of sectorial composition, OLS and WALS ....................................... 29

Table 3. Regression results of fiscal and monetary response, OLS and WALS ............................ 30

Table 4. Regression results of regulation, OLS and WALS ...................................................... 30

Table 5. Regression results of macroeconomics characteristics, OLS and WALS ...................... 31

Table 6. Regression results of development, demographic and institutions, OLS and WALS .... 32

Table 7. Robust drivers of output performance across countries-WALS ................................. 33

Table 8. Robust drivers of output performance across countries — controlling for outliers .......... 34

Table 10. Robust drivers of output performance across countries—additional covariates ........... 36 


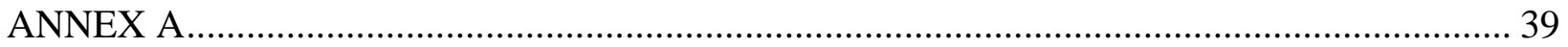

Table A1. Sources and descriptive statistics of the variables used in the analysis.................. 39

Figure A1. Output performances (\%) and public health....................................................... 41

Figure A2. Output performances (\%) and sectoral composition ............................................ 41

Figure A3. Output performances $(\%)$ and fiscal and monetary response ................................. 42

Figure A4. Output performances (\%) and regulation ......................................................... 42

Figure A5. Output performances (\%) and macroeconomics characteristics............................ 43

Figure A6. Output performances (\%) and development, demographic and institutions .......... 44

Figure A7. Robust drivers of output performance across countries—controlling for outliers,

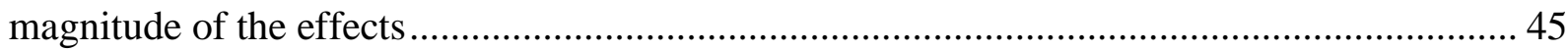

Figure A8. Robust drivers of output performance across countries - additional covariates,

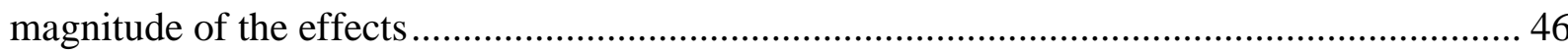

Figure A9. Robust drivers of output performance across countries - using Q2 deviation as

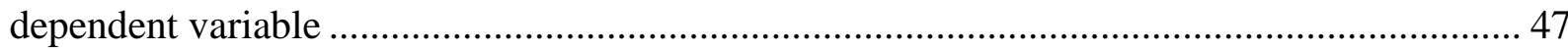

Figure A10. Robust drivers of output performance across countries - interaction with income

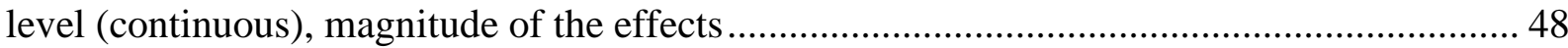

Figure A11. Robust drivers of output performance across countries - interaction with income

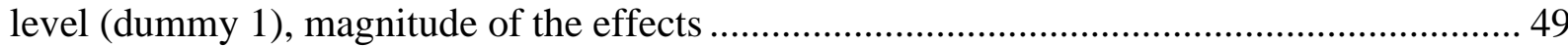

Figure A12. Robust drivers of output performance across countries - interaction with income level (dummy 2), magnitude of the effects .......................................................................... 50

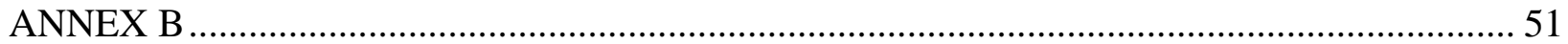




\section{INTRODUCTION}

The magnitude of the COVID-19 recession is unprecedented, and easily dwarfs the blow from the Global Financial Crisis (IMF, 2020). Initial output losses, however, vary considerably across countries. Figure 1a shows, for a sample of 60 advanced, emerging and developing economies, a density plot of growth in the first semester of 2020 minus the IMF pre-pandemic growth forecast. While all countries had a negative surprise, there is considerable variation. Unexpected growth is but a few percentage points in Korea but ranges to more than 30 percentage points in Peru. Such heterogeneity is also evident when comparing first semester growth in 2020 versus 2019 (Figure 1b).

What drives this heterogeneity? Because the pandemic is foremost a health crisis, a natural candidate is the severity of health-related factors measured for example by: deaths per capita; degree of health preparedness; and stringency of containment. These factors, however, explain only a small fraction of observed output performance (Figure 2), suggesting the researcher need look elsewhere for a fuller explanation.

Assessing which factors drive the heterogeneous outcomes is not an easy task, for three interrelated reasons. First, the number of observations is relatively small and limited by the number of countries with available quarterly data. Second, the number of potential factors affecting economic resilience is large. Third, many of the country characteristics are correlated with one other: the level of regulation in product and financial markets is likely to be correlated with the level of development, for example (Alesina et al., 2020).

We address these issues by considering a large set of explanatory variables and analyzing all the regressors jointly by averaging outcomes for all possible combinations of regressors (more than 1.07 billion regressions) using model-averaging techniques: Weighted Average Linear Squared (WALS) developed by Magnus, Powell, and Prüfer (2010); and Bayesian Model Averaging (BMA) developed by Fernandez, Ley and Steel (2001a). WALS and BMA share similar foundations. There are two main differences. First, WALS relies on a preliminary orthogonal transformation of the auxiliary regressors and their parameters, whose advantage is to increase speed of computation. Second, while WALS uses a Laplace distribution to reduce the risk of excessive influence of the prior on final estimates, BMA uses a Gaussian distribution prior for the auxiliary parameters. Reflecting these tradeoffs, we use WALS as our baseline technique, and adopt the BMA as a robustness check. 
We focus on the acute phase of the crisis because most countries are already recording positive growth in the third quarter of 2020 and the factors affecting recovery are different from those driving the downturn. ${ }^{1}$ We consider two measures of output performance: (i) actual growth in the first semester of 2020 minus the January 2020 IMF growth forecast for this period; and (ii) growth in the first semester of 2020 minus the growth rate for the first semester of 2019.

We find that larger output losses are experienced by countries with lower GDP per capita, more stringent containment, higher deaths per capita, a larger tourism share, more liberalized credit markets, higher pre-crisis growth, and more democratic regimes. We also find that lower fiscal stimulus and higher social fractionalization are positively correlated with one measure of output loss. GDP per capita is particularly important: a country at the $75^{\text {th }}$ percentile of the per capita GDP distribution (such as Portugal) has a 7-percentage-point smaller growth surprise than a country at the $25^{\text {th }}$ percentile (such as Bangladesh). This result reflects higher economic costs of containment and deaths in poorer countries and less effective macro policy stimulus.

Our paper contributes to two strands of the literature. The first is on resilience following major crises such as the GFC: Rose (2011); Rose and Spiegel (2010, 2011, 2012); Giannone, Lenza and Reichlin (2011); Obstfeld et al. (2009); Blanchard et al. (2010); Devereux and Dwyer (2016). In contrast to these studies, we do not find that trade and financial openness have been important drivers of output surprises in our study. The second is on use of Bayesian modelaveraging techniques in the macroeconomic literature, including studies focusing on robust drivers of growth (e.g., Fernandez et al., 2001b; Brock and Durlauf, 2001; and Sala-i-Martin et al., 2004), inequality (Furceri and Ostry, 2019) and reforms (Duval, Furceri and Mieithe, 2020).

The rest of the paper is structured as followed. In Section II, we provide an overview of our empirical approach. In Section III, we introduce potential determinants of COVID-19 output losses. In Section IV, we summarize these results and provide an overall assessment of the statistical robustness of the determinants. Sections V concludes, highlighting policy implications and issues for future research.

\footnotetext{
${ }^{1}$ While for many countries the peak of the economic crisis was observed in the second quarter, the pandemic had inflicted significant human losses already in the first quarter of 2020 for most countries in our sample. In addition, most countries had already introduced travel restrictions - one important factor behind output losses for countries relying on tourism - in response to the initial outbreak in China and Asia (Deb et al. 2020a). Finally, by including the first quarter, we also take into account potential growth spillovers from the downturn in China in the first quarter. As we show in the robustness checks, the results are similar when restricting the analysis to the second quarter of 2020.
} 


\section{EMPIRICAL FRAMEWORK}

Although there is a voluminous literature on the determinants of economic recessions, cross-sectional information has not been fully exploited to study the drivers of the COVID-19 recession, and theory provides little guidance on appropriate model specification. Therefore, we start from a simple linear reduced from specification:

$$
Y_{i}=\alpha+\beta X_{i}+\mu_{i}
$$

where $X$ is a vector of k covariates reflecting characteristics of economy $i$ along different dimensions, and $Y$ is a measure of output performance. Such an approach needs to confront two econometric challenges: (i) the large number of potential explanatory factors and correlation among them; and (ii) lack of an a priori "true" statistical model to test. With an unknown true model, the number of possible independent variables is very large. Depending on the model selection procedure, conclusions could vary significantly.

To meet these concerns, the literature has turned to model-averaging techniques. ${ }^{2}$ Modelaveraging addresses the challenges by: (i) running the maximum combination of models; and (ii) providing estimates that take into account the performance of each potential driver not only in the final "reported" model but over the whole set of possible specifications. Formally, assuming that we are faced with $M$ different models and that $\beta_{x}$ is the coefficient related to variable $X$ in each model, a final estimate of $\beta_{x}$ is computed as $\beta_{x}=\sum_{1}^{M} \omega_{i} \beta_{x, i}$, where the weights $\omega_{i}$ denote a measure of goodness of fit of each model.

In this paper, we rely on two model-averaging techniques: Weighted Average Linear Squares (WALS) developed by Magnus, Powell, and Prüfer (2010), and Bayesian Model Averaging (BMA) developed by Fernandez, Ley and Steel (2001a). WALS and BMA share similar foundations. There are, however, two main differences. First, WALS relies on a preliminary orthogonal transformation of the auxiliary regressors and their parameters. The key

\footnotetext{
${ }^{2}$ Fernandez et al. (2001b), Brock and Durlauf (2001) and Sala-i-Martin et al. (2004) used BMA to investigate robustness of growth determinants in cross-country regressions. Furceri and Ostry (2019) used BMA to identify robust determinants of income inequality across and within-countries. Duval, Furceri and Mieithe (2020) used Bayesian averaging of maximum likelihood estimates (BAMLE) to identify robust drivers of structural reforms.
} 
advantage of this transformation is that the space over which model selection is performed rises linearly rather than exponentially with model size as in BMA $\left(2^{K 2}\right.$ where $K 2$ is the number of “auxiliary” regressors to be tested). Second, while WALS uses a Laplace distribution to reduce risks of excessive influence of the prior on final estimates, BMA uses a Gaussian prior for the auxiliary parameters (see Annex B). Reflecting these considerations, we use WALS as our baseline technique, and adopt BMA as a robustness check.

To decide which regressors are robust determinants of output loss, we follow the literature. For WALS, Magnus, Powell, and Prüfer (2010) suggest using a threshold value of the t-statistic - greater than 1 (in absolute value) — to determine that a regressor is robust. Using such a threshold means including regressors which improve the model fit (measured by the adjusted $\mathrm{R}^{2}$ ) and the precision of the estimators measured by the MSE. For BMA, the procedure involves estimating the posterior probability that a given variable belongs in the "true" model and selecting variables with high posterior probabilities as the robust determinants.

While model averaging addresses model uncertainty and omitted variable bias, it does not address reverse-causality issues — where event studies may be appropriate. While reverse causality is not an issue for many of the more structural characteristics used in our analysis, it may be a valid concern for policies implemented in response to the pandemic.

\section{Potential Determinants}

Variable selection is driven to an important extent by data availability. Given the small number of quarterly GDP growth observations (96), we constrain the choice and number of variables so that we are left with enough degrees of freedom for estimation. The set of regressors in the baseline includes 30 variables grouped into six categories: (i) Public health; (ii) Sectoral composition; (iii) Fiscal and monetary response; (iv) Macroeconomic characteristics; (v) Regulation; and (vi) Development level, Demographics and Institutions. In the robustness section, where we extend the set of regressors to 34, the results based on the more limited (fullmodel) sample of 48 observations are qualitatively similar but less precise. Data sources and key descriptive statistics are reported in Table A1 of Annex A. 


\section{A. Public Health Indicators}

Countries with higher per capita deaths should experience greater output losses through reduced labor supply and greater demand-reducing social distancing (Maloney and Taskin, 2020). Hasell (2020) finds a negative relationship between deaths per capita and year-over-year growth in the second quarter of 2020, supporting this prior. Stringency of non-pharmaceutical (containment) measures, designed to avoid overwhelming the medical system while effective treatments and vaccines are developed, is associated with short-term output loss. Main measures include: (i) school closures; (ii) workplace closures; (iii) cancellation of public events; (iv) restrictions on size of gatherings; (v) closures of public transport; (vi) stay-at-home orders; (vii) restrictions on internal movement; (viii) restrictions on international travel. ${ }^{3}$ Likewise, countries with better health systems in terms of epidemic management and prevention are expected to suffer smaller economic losses (Deb et al. 2020b).

To test the empirical relevance of these factors, we use the following three variables: (i) $\log$ of deaths per capita - cumulative deaths as of June 30 relative to population; (ii) the containment stringency index from the Oxford Coronavirus Government Response Tracker, normalized from 0 to $1 ;{ }^{4}$ and (iii) the Global Health Security Index from Johns Hopkins University. ${ }^{5}$ Figure 2 presents scatter plots between these measures and our first measure of output loss (the second measure is shown in the Appendix). Output loss is larger for countries with higher mortality and containment, while no relation is found with the Health Security Index, or any of its sub-indicators. OLS and WALS regressions confirm these findings (Table 1).

\footnotetext{
${ }^{3}$ A growing economic literature has looked at the economic impact of containment measures using high-frequency indicators: Carvalho et al. (2020); Chronopoulos, Lukas, and Wilson (2020); Deb et al. (2020a); Demirgüç -Kunt, Lokshin, and Torre (2020); Baek et al. (2020); Baker et al. (2020); Béland, Brodeur, and Wright (2020); Chernozhukov, Kasahara, and Schrimpf (2020); Coibion, Gorodnichenko and Weber (2020); Gupta et al. (2020).

${ }^{4}$ The Oxford Coronavirus Government Response Tracker collects information on government policy responses across the eight dimensions given above. The database scores the stringency of each measure ordinally, for example, depending on whether the measure is a recommendation or a requirement and whether it is targeted or nationwide. We normalize each measure to range between 0 and 1 to make them comparable.

${ }^{5}$ Index based on health scores for the following six categories: (i) prevention of the emergence or release of pathogens; (ii) early detection and reporting for epidemics of potential international concern; (iii) rapid response to and mitigation of the spread of an epidemic; (iv) sufficient and robust health system to treat the sick and protect health workers; (v) commitments to improving national capacity, financing plans to address gaps, and adhering to global norms; and (vi) overall risk environment and country vulnerability to biological threats.
} 


\section{B. Industry Shares}

Recessions tend to have heterogenous effects across industries. Evidence from past recessions and financial crises in advanced economies suggests that finance and manufacturing tend to contract more than other sectors during downturns (Aaronson, Rissman, and Sullivan, 2004; Furceri et al., 2020), while services tend to be more resilient (Kopelman and Rosen, 2016). However, because this crisis is foremost a health crisis and has been met with strong containment measures, high-contact sectors (such as tourism and retail) and non-teleworkable industries (mining, manufacturing, and construction) have been the ones to experience relatively large drops in activity (Stephany et al., 2020).

To test the role of sectoral composition, we consider three indicators (for 2019) from the World Development Indicators: shares of services, manufacturing, and tourism in value added (we exclude agriculture to avoid perfect collinearity). The scatter plot in Figure 3, as well as the OLS and WALS results reported in Table 2, confirm that services, and particularly tourism, have been hit the hardest during this crisis.

\section{Fiscal and Monetary Policies}

Governments and central banks have implemented unprecedented support measures in response to the pandemic. As of June 30, 2020, more than 90 countries had announced fiscal packages ranging in size from 1 to 23 percent of GDP (IMF's Covid-19 Policy Tracker). In addition, monetary policy rates have been cut in 97 countries from December 2019 to-June 2020 and many central banks have deployed unconventional tools. Preliminary evidence suggest that these measures have been effective in reducing the depth of the recession, especially in advanced economies where fiscal multipliers are higher and monetary policy transmission is more effective (Faria-e-Castro, 2020; Jinjarak et al., 2020; Fornaro and Wolf; Bayer et al., 2020).

To test the role of policy stimulus, we use the IMF's Covid-19 Policy Tracker measures of: (i) total fiscal stimulus (above and below the line) deployed (or announced); (ii) the cumulative change in the policy interest rate from December 2019 to June 2020; (iii) the amount of liquidity (in percent of GDP) injected by central banks from December 2019 to June 2020. Figure 4 shows that only policy rate cuts seem to be associated with lower output loss. Moreover, none of the variables is statistically significant when performing OLS and WALS regressions (Table 3). While lack of significance could be due omitted variable bias or reverse causality-as 
countries may provide more support in response to weak activity, it could also reflect the lack of a causal impact for two reasons: first, some of the fiscal measures have been announced but not yet implemented; and second, it may take time for policy stimulus to affect activity. In addition, it is likely that impacts are heterogeneous across countries, an issue explored below.

\section{Regulation}

Labor and product market regulations can affect realized output losses given the shifts of labor across industries in response to the pandemic. Evidence from past recessions and financial crises suggest that countries with more flexible product and labor market regulations are more resilient (Eichhorst et al., 2010; Artha and de Haan, 2011; Bernal-Verdugo et al., 2012; Bluedorn et al., 2019). ${ }^{6}$ The relationship between resilience and credit market regulation is less settled. While liberalized markets contribute to financial depending and lower volatility (Beck and Demirguc-Kunt, 2009), in the short term they may amplify volatility: Caprio and Honohan (2002) find that banking systems less subject to monitoring exhibit more procyclicality; Giannone et al. (2011) find a negative correlation between credit market liberalization and output growth during the GFC.

To test the role of regulatory variables, we consider the most recent observation (typically, 2019) for the following indicators from the Fraser Institute Index of Economic Freedom: (i) credit market deregulation, which includes ownership of banks, competition, and extension of credit; (ii) labor market deregulation, a composite index of hiring and firing practices; (iii) business deregulation, which assesses difficulty in starting a new business, including administrative rules and government bureaucracy. ${ }^{7}$ The indicators range from 0 to 10 , with higher values indicating less regulation. ${ }^{8}$ The scatter plots in Figure 5, as well as the WALS

\footnotetext{
${ }^{6}$ Another channel through which more flexible labor market can reduce the depth of the COVID-19 recession is by amplifying the effectiveness of fiscal stimulus (Cacciatore et al., 2020).

${ }^{7}$ We use the Fraser Institute dataset as it provides a greater country and time coverage than alternatives. The results are similar when using the indicators in Alesina et al. (2020) - see Table 10.

${ }^{8}$ The indicator of credit market regulation covers private ownership of banks, exposure to foreign competition, depth of private credit, and interest rate controls. The labor market indicator covers minimum wage regulation, hiring and firing practices, centralization of collective bargaining, unemployment benefits, and use of military conscription. Business regulation includes price controls, regulations for starting new businesses, government bureaucracy, import and export permits and exchange controls, tax assessments, and police protection.
} 
results in Table 4, confirm that countries with freer financial markets are less resilient. In contrast, we do not find robust significant relationship between other regulatory measures and both measures of output performance.

\section{E. Macroeconomic characteristics}

Macroeconomic fundamentals can play a substantial role in mitigating output losses during a crisis. One reason is that crises usually come with excess volatility and increases in uncertainty (Ahir et al., 2018) which can lead to significant outflows of capital in countries with large imbalances (McQuade and Schmitz, 2017; Aizenman and Pasricha, 2010). Domestic imbalances, such as a high debt-to-GDP ratios, can also affect resilience by reducing fiscal space, and constraining counter-cyclical policies (Ostry et al., 2010; Kim and Ostry, 2018).

Financial markets can also affect resilience. On the one hand, financial depth can foster risk-sharing across economic agents, enhance consumption smoothing and dampen the effect of cyclical shocks (Beck et al. 2009; Ostry et al., 2009). On the other, excess leverage can lead to larger output losses during periods of financial stress (Feldkircher, 2014; Berkmen et al., 2012; Devereux and Dwyer, 2016; Frankel and Saravelos, 2010; Cecchetti et al., 2011; Babecký, 2012, Babecký, 2013; Caprio et al., 2014).

Trade and financial linkages have also played an amplification role in past crises. Blanchard et al. (2010) find that the economic performance in trading partners was a strong predictor of output loss during the GFC, while Claessens et al. (2012) find that the GFC exerted a larger impact on trade-dependent firms; Groot et al. (2011), Ho (2010), Levchenko et al. (2010) and Demir and Javorchik (2020) also stress the role of the trade channel. In a similar vein, Rodrik (1998), Bhagwati (1998) and Stiglitz (2002) argue that financial integration induces volatility in times of recession and endangers financial stability (see Kose et al., 2009), while Rose (2011) and Rose and Spiegel (2012) show that greater financial exposure to the United States was not associated with larger output losses in the GFC. Exchange rate flexibility may also affect resilience in the face of external shocks (Ghosh, Ostry and Wolf, 1997; Ghosh, Ostry and Tsangarides, 2011; Ghosh, Ostry and Qureshi, 2015).

To test the role of these factors, we consider the most recent pre-crisis value of the following variables: (i) current account balance as a share of GDP; (ii) general government debtto-GDP ratio; (iii) financial system deposits as a percent of GDP; (iv) bank concentration; (v) 
domestic credit as a percent of GDP; (vi) and (vii) trade and financial globalization indices developed by the KOF Swiss Economic Institute; and (viii) an exchange rate regime variablewhich assumes 1 for fixed; 2 for intermediate and 3 for flexible-from the IMF. We also consider the three-year average GDP growth preceding the COVID-19 crisis to control for crosscountry heterogeneity in pre-crisis growth. Figure 6 presents scatter plots between output loss and each of these variables. Output performance seems weaker for countries with higher precrisis growth, greater financial development and openness, higher pre-crisis debt-to-GDP ratios and current account deficits. Among these variables, however, only the debt-to-GDP ratio and pre-crisis growth appear to be robust determinants of output performance (Table 5).

\section{F. Development level, Demographics and Institutions}

Development level (per capita GDP) may influence resilience, as containment measures may be costlier in poorer countries because of limited social safety nets and larger shares of financially-constrained households and firms. In addition, there is evidence that fiscal and monetary policy are more effective in advanced economies (Ilzetki et al., 2013 on fiscal policy; Brandao-Marques et al., 2020 on monetary policy). On the other hand, resilience could be enhanced in poorer economies as larger informal sectors reduce nominal rigidities (Mithra, 2013).

Income distribution may affect resilience: Wright et al. (2020) find that shelter-in-place policies are more effective in reducing virus spread in richer countries. Weill et al. (2020) show that social distancing measures reduce mobility more in wealthier areas. In addition to its effects through compliance with social distancing, inequality can affect resilience if more inequal societies have larger shares of vulnerable workers.

Turning to demographic characteristics, the pandemic is more serious in terms of symptoms and death for the elderly: Ioannidis et al. (2020) finds that $88-96 \%$ of people dying with or because of COVID-19 are 65 or above. In addition, the effect of the crisis on labor force dropouts is larger for older workers. Thus, countries with older populations are likely to suffer more from job loss due to injury, death or labor force dropout. Country size may also play a role: smaller economies are typically more volatile (Furceri and Karras 2007) while larger economies may find it more difficult and costly to manage public health services (Alesina et al. 2005). 
Finally, virus spread runs through social proximity, which is why high population density is associated with high case numbers.

Other factors we consider include: remittances; social fractionalization; and the nature of the political regime. The effect of remittances on resilience during a crisis is unclear as they tend to be countercyclical in the worker's country of origin and procyclical in the migrant's host country (Frankel 2011). Ethnic and religious fractionalizations can also affect output performance during a crisis by impairing the quality of the government and its policy response (Alesina et al., 2003). Finally, the type of political regime may shape both pandemic management and readiness of the public health system: democratic countries tend to have better public health systems (Ruger, 2005; Sen, 1999) which can give them an edge in fighting the disease (Kavanagh and Singh, 2020), but authoritarian governments may react faster and adopt drastic policy measures without fearing popular resistance. Cepaluni et al. (2020) show that more democratic countries face higher per capita deaths than less democratic countries do.

To assess the role of these factors, we consider the most recent pre-crisis value of: (i) the (log) of GDP per capita from the World Development Indicators (WDI); (ii) the Gini coefficient of after-tax income from the Standardized World Income Inequality Database; (iii) the share of population over 65; (iv) and (v) (log of) population and population density from the World Development Indicators; (vi) the share of remittances to GDP from the World Bank Financial Structure Database; (vii) a composite indicator of ethnic and religious fractionalization from Alesina et al. (2003); (viii) an indicator of informality from WDI; (vii) the level of democracy from Polity IV. Figure 7 suggests larger output losses in countries with lower GDP per capita, higher inequality, larger informal sectors, higher remittances and more democratic regimes. The evidence for inequality and informality are confirmed by the WALS results (Table 6).

\section{ROBUST DRIVERS}

Scatter plots and estimates based on a few covariates suggest that several factors are associated with output losses. But which factors are robust? To answer this question, we report WALS estimates of the most robust drivers for the two alternative measures of output loss mentioned earlier. To remind, a regressor is considered robust if the $t$-statistic in absolute value is larger than 1 -broadly speaking, this corresponds to a statistically significant increase in the adjusted $R^{2}$ due to the inclusion of that variable. 
The results confirm the associations highlighted earlier. Output performance is negatively related to: more stringent containment measures; higher deaths rates; a larger tourism share; less stringent credit market regulation; higher pre-crisis growth; and more democratic political regimes. Lower fiscal stimulus and higher social fractionalization are negatively correlated with at least one measure of output performance (Table 7).

In Figure 8 , we present the effect on output performance from moving from the $25^{\text {th }}$ to the $75^{\text {th }}$ percentile of each variable's distribution - that is, we multiply the WALS coefficient by the inter-quartile range. The results show that GDP per capita is quantitatively the largest player in driving output loss: a country at the $25^{\text {th }}$ percentile of the GDP per capita distribution (such as Bangladesh) has, on average, a 7 percentage point lower-than-expected output growth than a country at the $75^{\text {th }}$ percentile (such as Portugal). The next two positions in the ranking are containment measures and deaths, with similar magnitudes: an increase from the $25^{\text {th }}$ to the $75^{\text {th }}$ percentile of their distributions is associated with an increase in output losses of 41/2-5 percentage points. While these results confirm the large economic cost associated with containment, they also highlight the close relation between "saving lives" and "saving the economy."

Two other economically important drivers of resilience are tourism dependence and the democracy score. Countries with a large share of tourism - notably Caribbean and Pacific islands - experience a $3 \frac{1}{2}$ percentage point smaller than expected output growth along the interquartile range. In contrast, countries that score low in the Polity IV democracy index (such as China and Vietnam) are associated with significantly higher resilience (reductions of about 4 percentage points in output growth losses) than more democratic countries. As suggested by Cepaluni et al. (2020), this may reflect better enforcement of containment measures and compliance with social distancing as well as faster interventions to pandemic outbreaks.

\section{A. Robustness checks}

\section{Outliers}

Do outlier observations influence the results? To check, we winsorize the upper and lower 5 percentiles of the distribution of the dependent variables, and show in Table 8 (Figure 
A7) results to be broadly in line with the baseline in Table $7 .{ }^{9}$ For the first measure of output performance (column I), we confirm the same robust drivers, but higher fiscal stimulus becomes a robust driver of output performance. The results are also similar for the second output performance measure (column II), except that higher government debt is also robustly associated with lower output performance.

\section{$B M A$}

As discussed earlier, WALS is theoretically superior to BMA because, while BMA uses a Gaussian prior for the auxiliary parameters, WALS uses a Laplace distribution which reduces the risk of the prior overly influencing the final estimates. WALS is also practically superior because the space over which model selection is performed increases linearly rather than exponentially with size. At the same time, a key advantage of BMA is the larger number of models considered. To check robustness of our results, we repeat the analysis using BMA and consider the entire model space ( $2^{30}$ models). In Table 9 we report the posterior inclusion probability of each regressor - that is, the probability that a variable belongs to the true model. Similar to the baseline, the variables with the highest posterior probabilities are containment stringency, tourism and deaths per capita. Other variables that would enter in at least 10 percent of the $2^{30}$ $(1,073,741,824)$ models are typically those found to be robust in WALS such as, pre-crisis growth, credit market regulation, the level of GDP per capita and democracy. In addition, we find that the share of the elderly seems to be robust in BMA-with a 35 percent posterior probability to enter in all models for the second output loss measure.

\section{Additional determinants}

As mentioned earlier, the selection of the variables is partly dictated by data availability. To check robustness to the inclusion of additional factors, we expanded the set of controls to include: additional measures of regulation pertaining to trade, the current and capital accounts, and indicators of rule of law; the share of non-performing loans (NPL); a measure of poverty and the amount of central bank reserves in percent of imports. The results with this larger set of (36)

\footnotetext{
${ }^{9}$ To avoid further reducing sample size, winsorizing seems preferable to dropping observations. If we choose instead to drop outlying data, results are similar but effects are less precisely estimated.
} 
controls, based on a more limited sample of observations (and 11 degrees of freedom), confirm the baseline findings that GDP per capita, containment measures, deaths, and tourism are the most robust determinants of output performance (Table 9 and Figure A8). Additionally, we also find that countries with higher rule of law, higher debt-to-GDP ratios and smaller fiscal stimulus suffer higher output losses. In contrast, democracy is no longer significant, reflecting that in this restricted sample most countries have a similar democracy score and the democracy variable has a high negatively correlation with the rule of law indicator.

\section{Alternative period}

For many countries the peak of the economic crisis has been observed in the second quarter of 2020. It is useful to check, therefore, the validity of our results when considering only economic performance in the second quarter alone. Results reported in Table 11 (Figure A9) confirm our previous findings, and also suggest that countries with higher debt-to-GDP ratio, larger current account surpluses and more flexible exchange rates tend to experience weaker economic performance.

\section{B. Cross-Country Heterogeneity: Mediating Channels}

The results suggest that differences in GDP per capita are the most robust and important drivers of cross-country differences in output loss. What drives this result? Potential mediating channels could be the higher economic costs of health crises and less effective macroeconomic stimulus in poorer countries. To shed light on this, we extend the specification to include interaction terms between three alternative measures of economic development and deaths per capita, the stringency of containment measures, and the monetary and fiscal policy response variables. The measures of economic development we consider are: (i) the level of GDP per capita; (ii) a dummy which takes value 1 for countries with a level of GDP per capita above the sample average; (iii) a dummy which takes value 1 for advanced economies (IMF definition).

The WALS results in Table 12 (Figure A10) highlight mediating channels consistent with our priors. First, output costs associated with containment measures and deaths are larger in lower-income countries, probably because of more limited social safety nets and larger shares of financially-constrained households and firms. Second, monetary stimulus - specially liquidity provisions - has been less effective in poorer countries, consistent with the literature on the more 
limited transmission of monetary policy in emerging market and developing economies. Third, there is some evidence that effectiveness of fiscal stimulus is lower in poorer countries.

\section{CONCLUSION}

This paper has explored the factors that drive heterogeneity of output losses across countries in the first phase of the Covid-19 recession. Using model-averaging techniques to address model uncertainty, we find that countries experiencing smaller output losses are those with: higher GDP per capita; less stringent containment measures; smaller number of deaths per capita; smaller tourism sectors; less flexible credit markets; lower pre-crisis growth; higher fiscal stimulus; less social (ethnic and religious) fractionalization; and less democratic regimes. Among these factors, the level of GDP per capita has the largest quantitative effect on resilience among the robust factors: a country at the $75^{\text {th }}$ percentile of the GDP per capita distribution (such as Portugal) has, on average, a 7 percentage point smaller output loss than a country at the $25^{\text {th }}$ percentile (such as Bangladesh). Our analysis suggests two key reasons why less-developed economies may be less resilient: the higher economic costs of containment measures_probably because of more limited social safety nets - and less effective fiscal and monetary policy stimulus.

We also find that death rates and containment stringency have similar effects on resilience, which suggests that rollback of containment should be implemented in a way that minimizes health risks. This implies relaxing containment only when new infections are declining and implementing strong testing and contact tracing policies. Second, fiscal stimulus has helped to reduce economic losses, underscoring that premature withdrawal of such stimulus is self-defeating. Our results indicate that monetary stimulus enhanced resilience more in advanced than non-advanced economies, underscoring the criticality of improving transmission in the latter. Third, reflecting that this is foremost a health crisis, the economic fallout has been particularly acute in high-contact sectors such as tourism and retail. This underscores the need for targeted rather than generalized support, particularly in the later stages of the crisis.

Our findings also speak to the more general literature on resilience. In contrast to studies on the GFC, we do not find that trade and financial openness have been important drivers of output loss during the pandemic. Whether such factors will play a key role going forward, including during the recovery, is an important question for future research. 


\section{References}

Aaronson, D., Rissman, E.R. and Sullivan, D.G., 2004. Can sectoral reallocation explain the jobless recovery?. Economic Perspectives-Federal Reserve Bank of Chicago, 28, pp. 36-49.

Ahir, Hites, Bloom, N., and Furceri, D., 2018. "World Uncertainty Index," Stanford, mimeo.

Aizenman, J., and Pasricha, G. K., 2010. Selective swap arrangements and the global financial crisis: Analysis and interpretation. International Review of Economics \& Finance, 19(3), pp. 353-365.

Alesina, A., Devleeschauwer, A., Easterly, W., Kurlat, S. and Wacziarg, R., 2003. Fractionalization. Journal of Economic growth, 8(2), pp. 155-194.

Alesina, A., Spolaore, E., and Wacziarg, R., 2005. "Trade, Growth and the Size of Countries," Handbook of Economic Growth, ed. by P. Aghion, and S. Durlauf, 1 (23), pp. 1499-1542. Elsevier.

Alesina, A.F., Furceri, D., Ostry, J.D., Papageorgiou, C. and Quinn, D.P., 2020a. "Structural Reforms and Elections: Evidence from a World-Wide New Dataset (No. w26720).” National Bureau of Economic Research.

Artha, I. K. D. S., and de Haan, J., 2011. Labor market flexibility and the impact of the financial crisis. Kyklos, 64(2), pp. 213-230.

Babecký, J., Havranek, T., Mateju, J., Rusnák, M., Smidkova, K., and Vasicek, B., 2012. Banking, debt and currency crises: early warning indicators for developed countries. No 1485, Working Paper Series, European Central Bank.

Babecký, J., Havránek, T., Matějů, J., Rusnák, M., Šmídková, K., and Vašíček, B., 2013. Leading indicators of crisis incidence: Evidence from developed countries. Journal of International Money and Finance, 35, pp. 1-19.

Baek, I. and Bouzinov, M., 2020. Does democratic progress deter terrorist incidents? European Journal of Political Economy, pp. 101951.

Baker, Scott R., Farrokhnia, R.A., Meyer, S., Pagel, M., and Yannelis, C., 2020. "How Does Household Spending Respond to an Epidemic? Consumption during the 2020 COVID-19 Pandemic." NBER Working Paper 26949, National Bureau of Economic Research.

Bayer, C., Born, B., Luetticke, R., and Müller, G. J., 2020. The Coronavirus Stimulus Package: How large is the transfer multiplier? CEPR Discussion Papers 14600, C.E.P.R. Discussion Papers.

Beck, T. and Demirguc-Kunt, A., 2009. Financial institutions and markets across countries and over time-data and analysis. The World Bank.

Béland, L.P., Brodeur, A. and Wright, T., 2020. The short-term economic consequences of Covid-19: exposure to disease, remote work and government response.

Benmelech Efraim and Nitzan Tzur-Ilan, 2020. "The Determinants of Fiscal and Monetary Policies During the Covid-19 Crisis," NBER Working Papers 27461.

Berkmen, S. P., Gelos, G., Rennhack, R., and Walsh, J. P., 2012. The global financial crisis: Explaining cross-country differences in the output impact. Journal of International Money and Finance, 31(1), pp. 42-59.

Bernal-Verdugo, Lorenzo E., Furceri, D., and Guillaume, D., 2013. "Banking crises, labor reforms, and unemployment," Journal of Comparative Economics, Elsevier, 41(4), pp. 1202-1219.

Bhagwati, J., 1998. The capital myth: the difference between trade in widgets and dollars. Foreign Affairs, pp. 7-12. 
Blanchard, O. J., Faruqee, H., Das, M., Forbes, K. J., and Tesar, L. L., 2010. The initial impact of the crisis on emerging market countries [with comments and discussion]. Brookings papers on economic activity, pp. 263-323.

Bluedorn, J., Aiyar, S., Duval, R., Furceri, D., Garcia-Macia, D., Ji, Y., Malacrino, D., Qu, H., Siminitz, J., and Zdzienicka, A., 2019. "Strengthening the Euro Area; The Role of National Structural Reforms in Building Resilience," IMF Staff Discussion Notes, 2019/005.

Brandao-Marques, L., Gelos, G., Harjes, T., Sahay, R. and Xue, Y., 2020. Monetary policy transmission in emerging markets and developing economies. IMF Working Papers 2020/035, International Monetary Fund.

Brock, W. A., and Durlauf, S. N., 2001. "What have we learned from a decade of empirical research on growth? Growth empirics and reality," The World Bank Economic Review, 15(2), pp. 229-272.

Cacciatore, M., Duval, R., Furceri, D., and Zdzienicka, A., 2020. "Fiscal Multipliers and JobProtection Regulation," European Economic Review, forthcoming.

Caprio, G. and Honohan, P., 2002. Banking policy and macroeconomic stability: An exploration. The World Bank.

Caprio Jr., G., D’Apice, V., Ferri, G., and Puopolo, G. W., 2014. Macro-financial determinants of the great financial crisis: Implications for financial regulation. Journal of Banking \& Finance, 44, 114-129.

Carvalho, V.M., Hansen, S., Ortiz, A., García, J.R., Rodrigo, T., Mora, S.R., and Ruiz, J., 2020. "Tracking the COVID-19 Crisis with High-Resolution Transaction Data." CEPR Discussion Paper 14642, Centre for Economic Policy Research.

Cecchetti, S. G., King, M., and Yetman, J., 2011. Weathering the financial crisis: good policy or good luck? BIS Working Papers 351, Bank for International Settlements.

Cepaluni, G., Dorsch, M., and Branyiczki, R., 2020. Political Regimes and Deaths in the Early Stages of the COVID-19 Pandemic. Social Science Research Network 3586767.

Chernozhukov, V., Kasahara, H. and Schrimpf, P., 2020. Mask mandates and other lockdown policies reduced the spread of COVID-19 in the US.

Chronopoulos, D.K., Lukas, M. and Wilson, J.O., 2020. Consumer Spending Responses to the COVID-19 Pandemic: An Assessment of Great Britain. Social Science Research Network 3586723.

Claessens, S., Tong, H., and Wei, S. J., 2012. From the financial crisis to the real economy: Using firm-level data to identify transmission channels. Journal of International Economics, 88(2), pp. 375-387.

Coibion, O., Gorodnichenko, Y. and Weber, M., 2020. The cost of the covid-19 crisis: Lockdowns, macroeconomic expectations, and consumer spending No. w27141. National Bureau of Economic Research.

Correia, S., Luck, S., and Verner, E., 1918. Pandemics Depress the Economy, Public Health Interventions Do Not: Evidence from the 1918 Flu. Public Health Interventions do not: Evidence from the 1918.

Cuaresma, J. C., and Feldkircher, M., 2012. Drivers of output loss during the 2008-09 crisis: a focus on emerging Europe. Focus on European Economic Integration, 2(12), pp. 46-64.

Deb, P., Furceri, D., Ostry, J. D., and Tawk, N., 2020a. The economic effects of Covid-19 containment measures. IMF Working Paper No. 20/158.

Deb, P., Furceri, D., Ostry, J. D., and Tawk, N., 2020b. The effect of containment measures on the COVID-19 pandemic. IMF Working Paper No. 20/159. 
Demir, B., and Javorcik, B., 2020. Trade finance matters: evidence from the COVID-19 crisis. Oxford Review of Economic Policy, 36(Supplement_1), S397-S408.

Demirguc-Kunt, A., Lokshin, M. and Torre, I., 2020. The sooner, the better: The early economic impact of non-pharmaceutical interventions during the COVID-19 pandemic. World Bank Policy Research Working Paper, 9257.

Devereux, J., and Dwyer, G. P., 2016. What determines output losses after banking crises?. Journal of International Money and Finance, 69, pp. 69-94.

Devereux, M. B., Young, E. R., and Yu, C., 2015. A new dilemma: Capital controls and monetary policy in sudden stop economies, No. w21791. National Bureau of Economic Research.

Didier, T., Hevia, C., and Schmukler, S. L., 2012. How resilient and countercyclical were emerging economies during the global financial crisis?. Journal of International Money and Finance, 31(8), pp. 2052-2077.

Duval, R., Furceri, D., and Miethe, J., 2020. Robust political economy correlates of major product and labor market reforms in advanced economies: Evidence from BAMLE for Logit Models. Journal of Applied Econometrics.

Eichhorst, W., Feil, M. T., and Marx, P., 2010. Crisis, what crisis? Patterns of adaptation in European labor markets. Applied Economics Quarterly (formerly: Konjunkturpolitik), Duncker \& Humblot, Berlin, vol. 61(Supplement), pages 29-64.

Faria-e-Castro, M., 2020. Fiscal policy during a pandemic. FRB St. Louis Working Paper, (2020006).

Feldkircher, M., 2014. The determinants of vulnerability to the global financial crisis 2008 to 2009: Credit growth and other sources of risk. Journal of international Money and Finance, 43, pp. 19-49.

Fernandez, C., Ley, E., and Steel, M. F., 2001a. Benchmark priors for Bayesian model averaging. Journal of Econometrics, 100(2), pp. 381-427.

Fernandez, C., Ley, E., and Steel, M. F., 2001b. Model uncertainty in cross-country growth regressions. Journal of applied Econometrics, 16(5), pp. 563-576.

Fornaro, L. and Wolf, M., 2020. Covid-19 coronavirus and macroeconomic policy. CREI/UPF and University of Vienna

Frankel, J.A., 2011. “Are Bilateral Remittances Countercyclical?,” Open Economies Review, 22(1), pp. 1-16.

Frankel, J. A. and Saravelos, G., 2010. Are leading indicators of financial crises useful for assessing country vulnerability? Evidence from the 2008-09 global crisis (No. w16047). National Bureau of Economic Research.

Frankel, J, and Saravelos, G., 2012. Can leading indicators assess country vulnerability? Evidence from the 2008-09 global financial crisis. Journal of International Economics, 87(2), pp. 216-231.

Furceri, D. and Ostry, J., 2019. Robust determinants of income inequality. Oxford Review of Economic Policy, 35(3), pp. 490-517.

Furceri, D., Celik, S. K., Jalles, J. T., and Koloskova, K., 2020. Recessions and Total Factor Productivity: Evidence from Sectoral data. Economic modelling.

Furceri, D. and Karras, G., 2007. "Country size and business cycle volatility: Scale really matters," Journal of the Japanese and International Economies, 21(4), pp. 424-434.

Ghosh, A.R., Ostry, J., and Qureshi, M.S., 2015. "Exchange Rate Management and Crisis Susceptibility: A Reassessment.” IMF Economic Review, 63(1), pp. 238-276. 
Ghosh, A.R., Ostry, J., and Tsangarides, C.G., 2011. "Exchange Rate Regimes and the Stability of the International Monetary System," IMF Occasional Paper 270.

Ghosh, A.R., Ostry, J., and Wolf, H., 1997. "Does the Nominal Exchange Rate Regime Matter?" NBER Working Paper 5874.

Giannone, D., Lenza, M., and Reichlin, L., 2011. "Market freedom and the global recession," IMF Economic Review, 59(1), pp. 111-135.

Gopinath, G., 2020. Global liquidity trap requires a big fiscal response. Viewed 10 November 2020, <https://www.ft.com/content/2e1c0555-d65b-48d1-9af3-825d187eec58>

Groot, S. P., Möhlmann, J.L., Garretsen, J. H., and de Groot, H. L., 2011. The crisis sensitivity of European countries and regions: stylized facts and spatial heterogeneity. Cambridge Journal of Regions, Economy and Society, 4(3), pp. 437-456.

Gupta, S., Montenovo, L., Nguyen, T.D., Rojas, F.L., Schmutte, I.M., Simon, K.I., Weinberg, B.A. and Wing, C., 2020. Effects of social distancing policy on labor market outcomes No. w27280. National Bureau of Economic Research.

Hasell, J., 2020. Which countries have protected both health and the economy in the pandemic. Our World in Data, 1.

Ho, T. K., 2010. Looking for a Needle in a Haystack: Revisiting the Cross-Country Causes of the 2008-09 Crisis. Economica.

Ilzetzki, E., Mendoza, E.G. and Végh, C.A., 2013. How big (small?) are fiscal multipliers?. Journal of monetary economics, 60(2), pp. 239-254.

International Monetary Fund (IMF). 2020. World Economic Outlook: A Long and Difficult Ascent. Washington, DC, October.

Ioannidis, J.P., Axfors, C., and Contopoulos-Ioannidis, D.G., 2020. Population-level COVID-19 mortality risk for non-elderly individuals overall and for non-elderly individuals without underlying diseases in pandemic epicenters. medRxiv.

Jinjarak, Y., Ahmed, R., Nair-Desai, S., Xin, W., and Aizenman, J., 2020. Pandemic shocks and fiscal-monetary policies in the Eurozone: COVID-19 dominance during January-June 2020 No. w27451. National Bureau of Economic Research.

Kavanagh, M. M., and Singh, R., 2020. Democracy, Capacity, and Coercion in Pandemic Response - COVID 19 in Comparative Political Perspective. Journal of Health Politics, Policy and Law.

Kim, J.I. and Ostry, J., 2018. "Boosting Fiscal Space: The Role of GDP-Linked Debt and Longer Maturities," IMF Discussion Paper 18/04. Forthcoming Economic Policy.

Kopelman, J.L. and Rosen, H.S., 2016. Are Public Sector Jobs Recession-Proof? Were They Ever?. Public Finance Review, 44(3), pp. 370-396.

Kose, M. A., Prasad, E., Rogoff, K., and Wei, S., 2009. Financial globalization: a reappraisal. IMF Staff papers, 56(1), pp. 8-62.

Levchenko, A A., Lewis, L. T., and Tesar, L. L., 2010. The collapse of international trade during the 2008-09 crisis: in search of the smoking gun. IMF Economic review, 58(2), pp. 214253.

Magnus, J. R., Powell, O., and Prüfer, P., 2010. A comparison of two model averaging techniques with an application to growth empirics. Journal of econometrics, 154(2), pp. 139-153.

Maloney, W. and Taskin, T., 2020. Determinants of social distancing and economic activity during COVID-19: A global view. Policy Research Working Paper Series 9242, The World Bank. 
McQuade, P. and Schmitz, M., 2017. The great moderation in international capital flows: A global phenomenon?. Journal of International Money and Finance, 73, pp.188-212.

Mitra, S., 2013. Informality, financial development and macroeconomic volatility. Economics Letters, 120(3), pp. 454-457.

Obstfeld, M., Shambaugh, J. C., and Taylor, A. M., 2009. Financial instability, reserves, and central bank swap lines in the panic of 2008. American Economic review, 99(2), pp. 480-86.

Ostry, J., Prati, A., and Spilimbergo, A., 2009. "Structural Reforms and Economic Performance in Advanced and Developing Countries," IMF Occasional Paper 268.

Ostry, J., Ghosh, A.R., Kim, J.I., and Qureshi, M.S., 2010. Fiscal Space. IMF Staff Position Note 2010/11.

Rodrik, D., 1998. Who needs capital-account convertibility?. Essays in international finance, pp. 55-65.

Rose, A. K., 2011. International financial integration and crisis intensity. Macroeconomics Working Paper 23195, East Asian Bureau of Economic Research.

Rose, A. K., and Spiegel, M. M., 2010. Cross-country causes and consequences of the 2008 crisis: International linkages and American exposure. Pacific Economic Review, 15(3), pp. 340-363.

Rose, A. K., and Spiegel, M. M., 2011. Cross-country causes and consequences of the crisis: An update. European Economic Review, 55(3), pp. 309-324.

Rose, A. K., and Spiegel, M. M., 2012. Cross-country causes and consequences of the 2008 crisis: early warning. Japan and the World Economy, 24(1), pp. 1-16.

Ruger, J. P., 2005. Democracy and health. Qjm, 98(4), pp. 299-304.

Sala-i-Martin, X., Doppelhofer, G., and Miller, R. I., 2004. Determinants of long-term growth: A Bayesian averaging of classical estimates (BACE) approach. American economic review, pp. 813-835.

Sen, A. K., 1999. Democracy as a universal value. Journal of democracy, 10(3), pp. 3-17.

Stephany, F., Stoehr, N., Darius, P., Neuhäuser, L., Teutloff, O., and Braesemann, F., 2020. The CoRisk-Index: A data-mining approach to identify industry-specific risk assessments related to COVID-19 in real-time. arXiv preprint arXiv:2003.12432.

Stiglitz, J.E., 2002. Globalization and its Discontents Vol. 500. Norton: New York.

Weill, J. A., Stigler, M., Deschenes, O., and Springborn, M. R., 2020. Social distancing responses to COVID-19 emergency declarations strongly differentiated by income. Proceedings of the National Academy of Sciences, 117(33), pp. 19658-19660.

Wright, A. L., Sonin, K., Driscoll, J., and Wilson, J., 2020. Poverty and economic dislocation reduce compliance with covid-19 shelter-in-place protocols. University of Chicago, Becker Friedman Institute for Economics Working Paper, 2020-40. 
Figure 1. Distribution of OUtPut PERFormanCes (\%)—DENSITY Plots

Panel A. Growth rate for the first semester of 2020 minus the January 2020 IMF Growth Forecast over the corresponding period

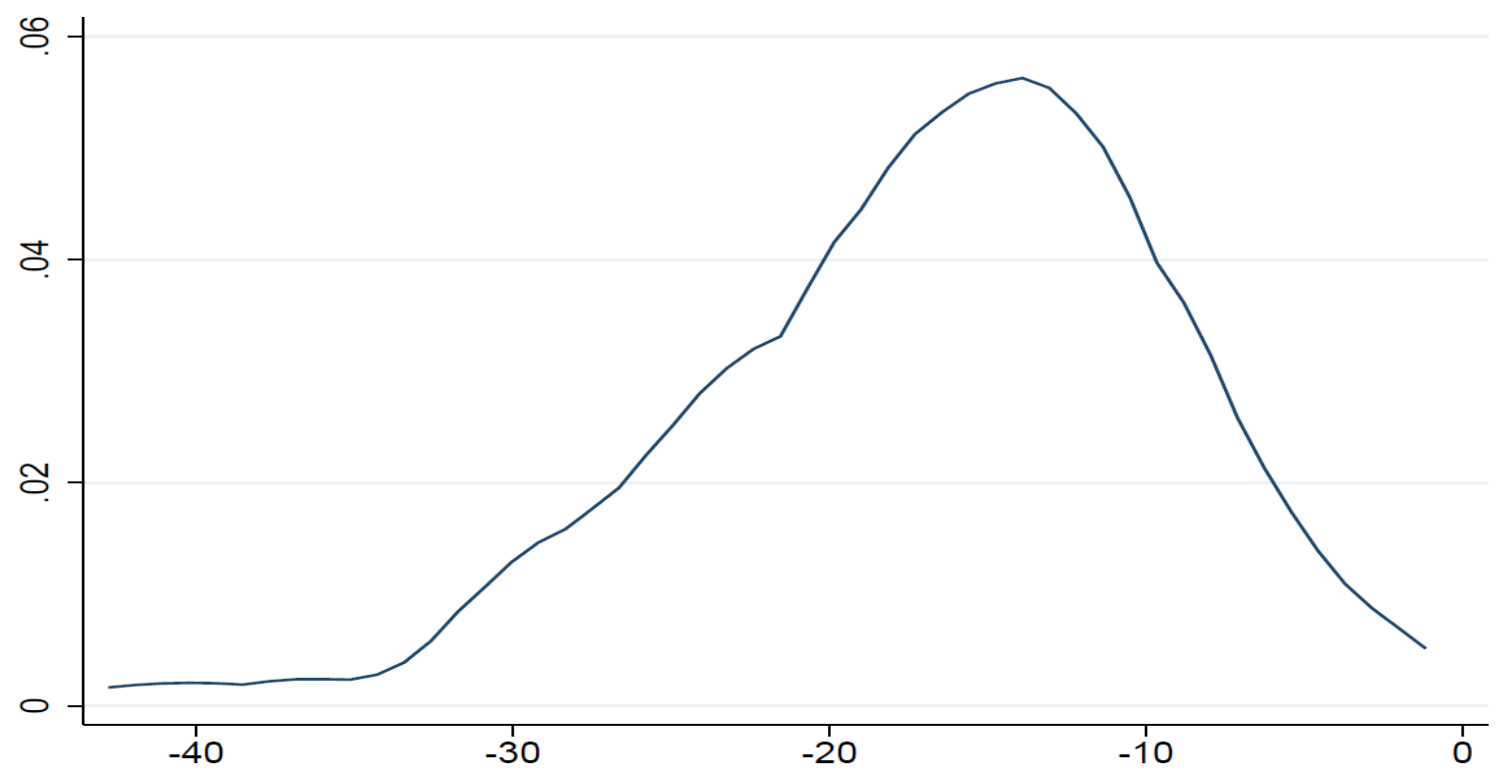

Panel B. Growth rate for the first semester of 2020 minus growth rate for the first semester of 2019

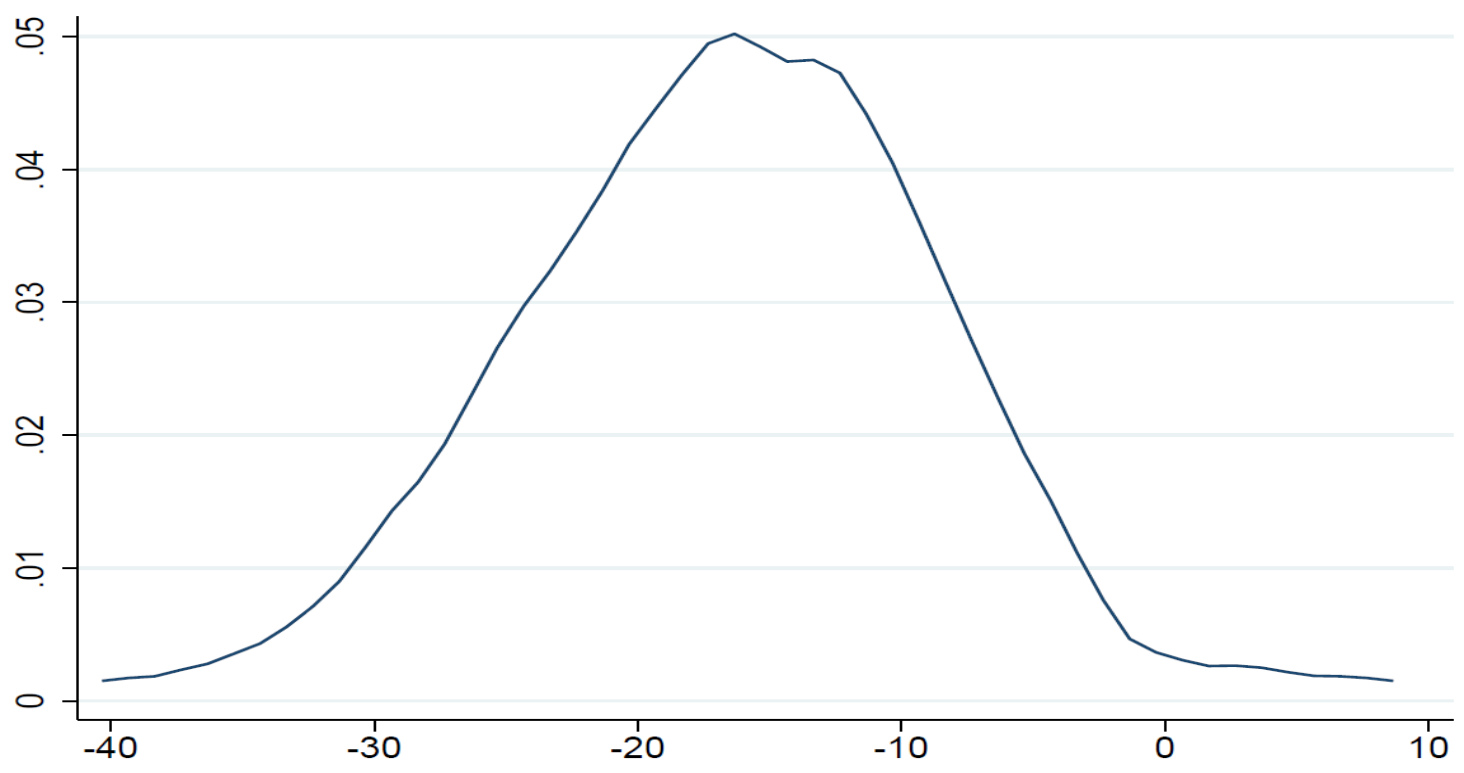


FIGURE 2. OUTPUT PERFORMANCES (\%) AND PUBLIC HEALTH

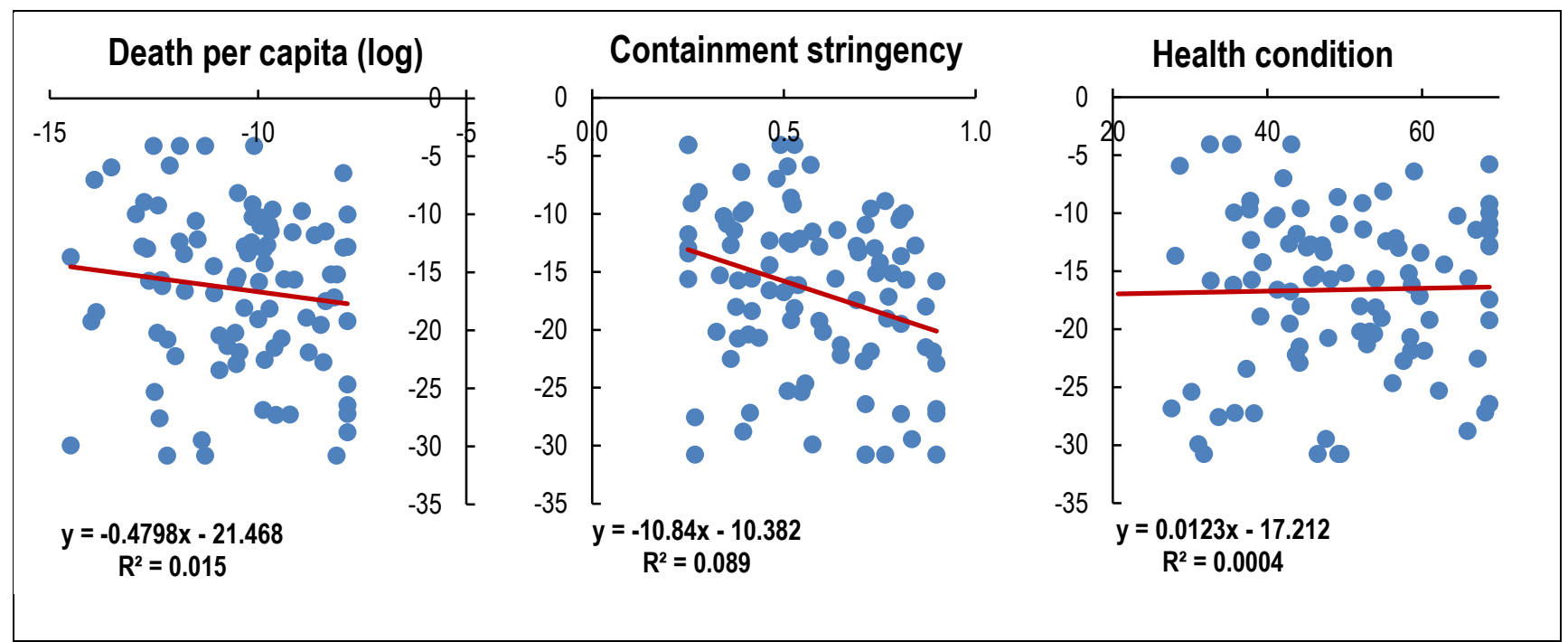

Note: Output performance is defined the difference between the observed cumulative real GDP growth in 2020H1 and the cumulative growth that was expected before the onset of the pandemic for the same period-based on the IMF World Economic Outlook 2020 January forecast for 2020H1.

FigurE 3. OUTPUT PERFORMANCES (\%) AND SECTORAL COMPOSITION

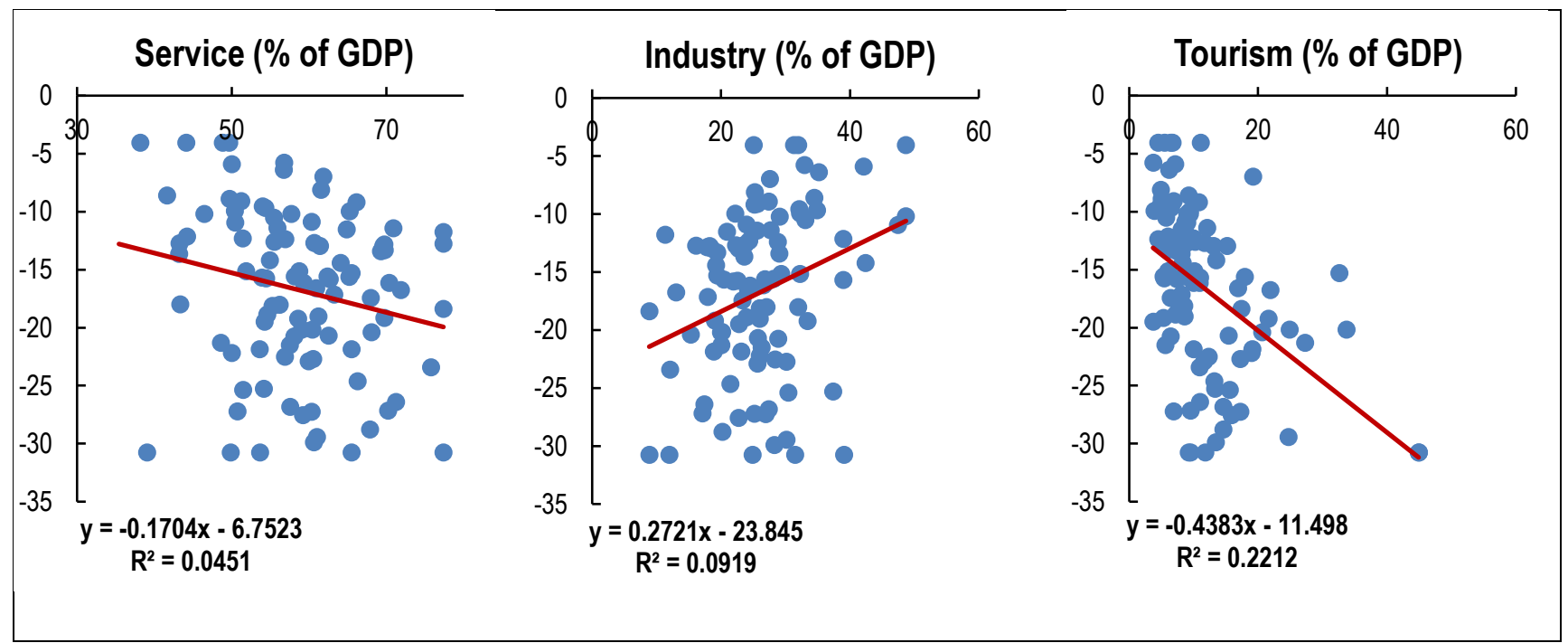

Note: Output performance is defined the difference between the observed cumulative real GDP growth in 2020H1 and the cumulative growth that was expected before the onset of the pandemic for the same period-based on the IMF World Economic Outlook 2020 January forecast for 2020H1. 
FigURE 4. OUTPUT PERFORMANCES (\%) AND FISCAL AND MONETARY RESPONSE

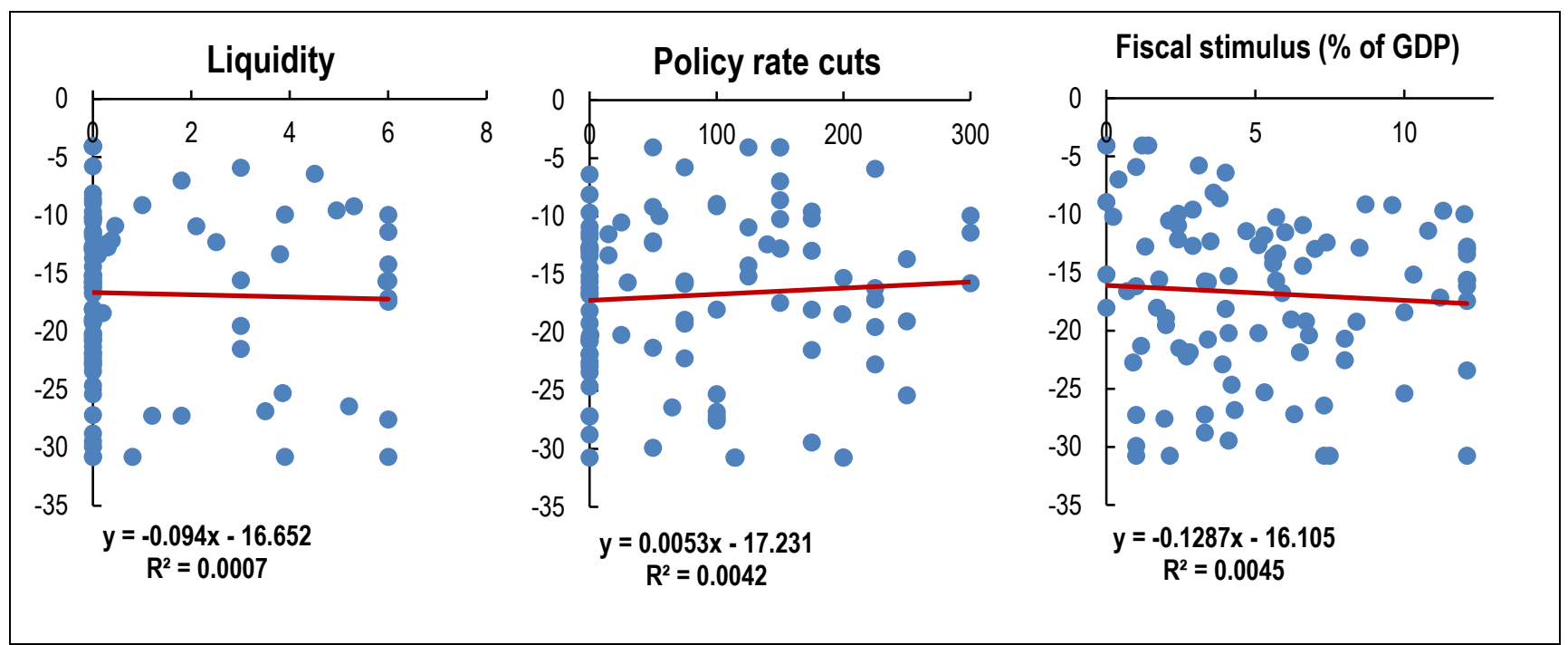

Note: Output performance is defined the difference between the observed cumulative real GDP growth in 2020H1 and the cumulative growth that was expected before the onset of the pandemic for the same period-based on the IMF World Economic Outlook 2020 January forecast for 2020H1.

FIGURE 5. OUTPUT PERFORMANCES (\%) AND REGULATION

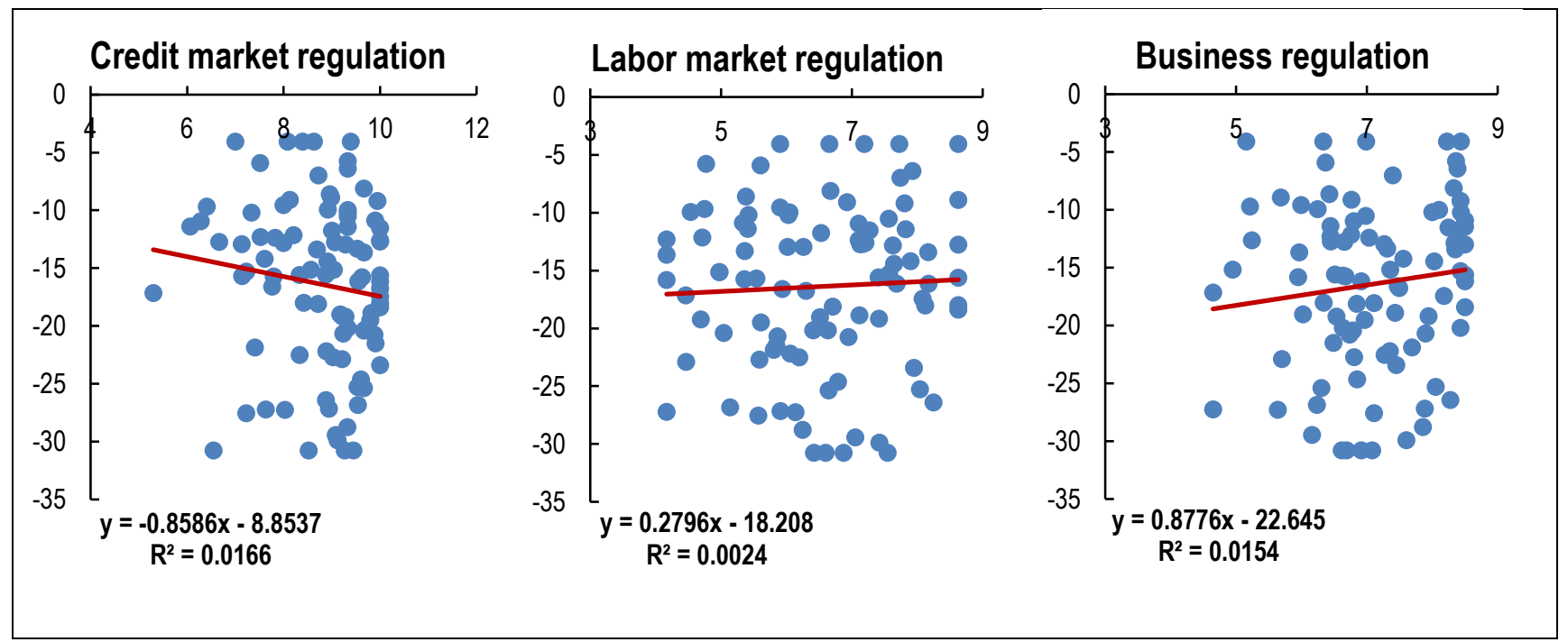

Note: Output performance is defined the difference between the observed cumulative real GDP growth in 2020H1 and the cumulative growth that was expected before the onset of the pandemic for the same period-based on the IMF World Economic Outlook 2020 January forecast for 2020H1. 
FIGURE 6. OUTPUT PERFORMANCES (\%) AND MACROECONOMICS CHARACTERISTICS

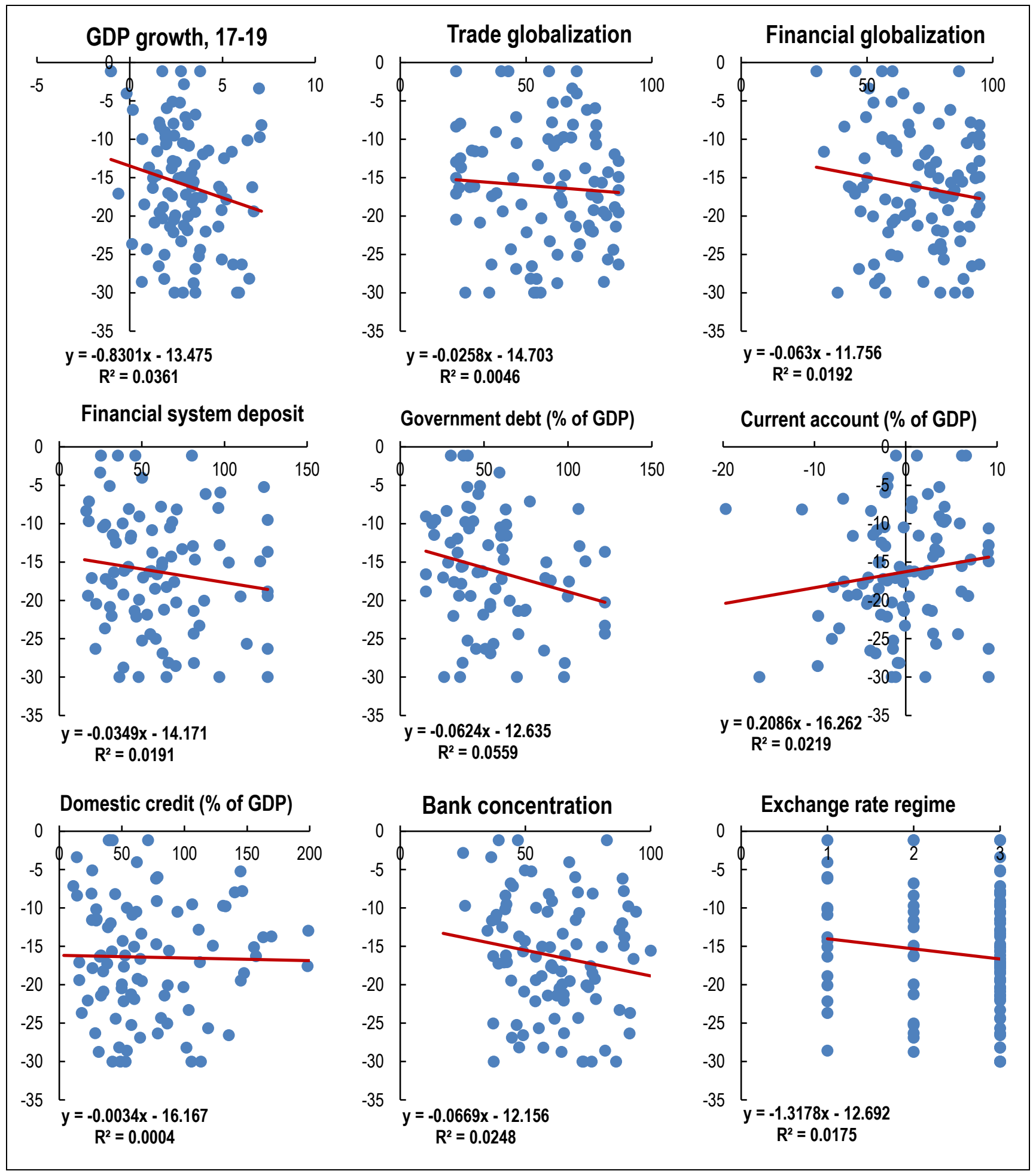

Note: Output performance is defined the difference between the observed cumulative real GDP growth in 2020H1 and the cumulative growth that was expected before the onset of the pandemic for the same period-based on the IMF World Economic Outlook 2020 January forecast for 2020H1. 
FigURE 7. OUTPUT PERFORMANCES (\%) AND DEVELOPMENT, DEMOGRAPHIC AND INSTITUTIONS

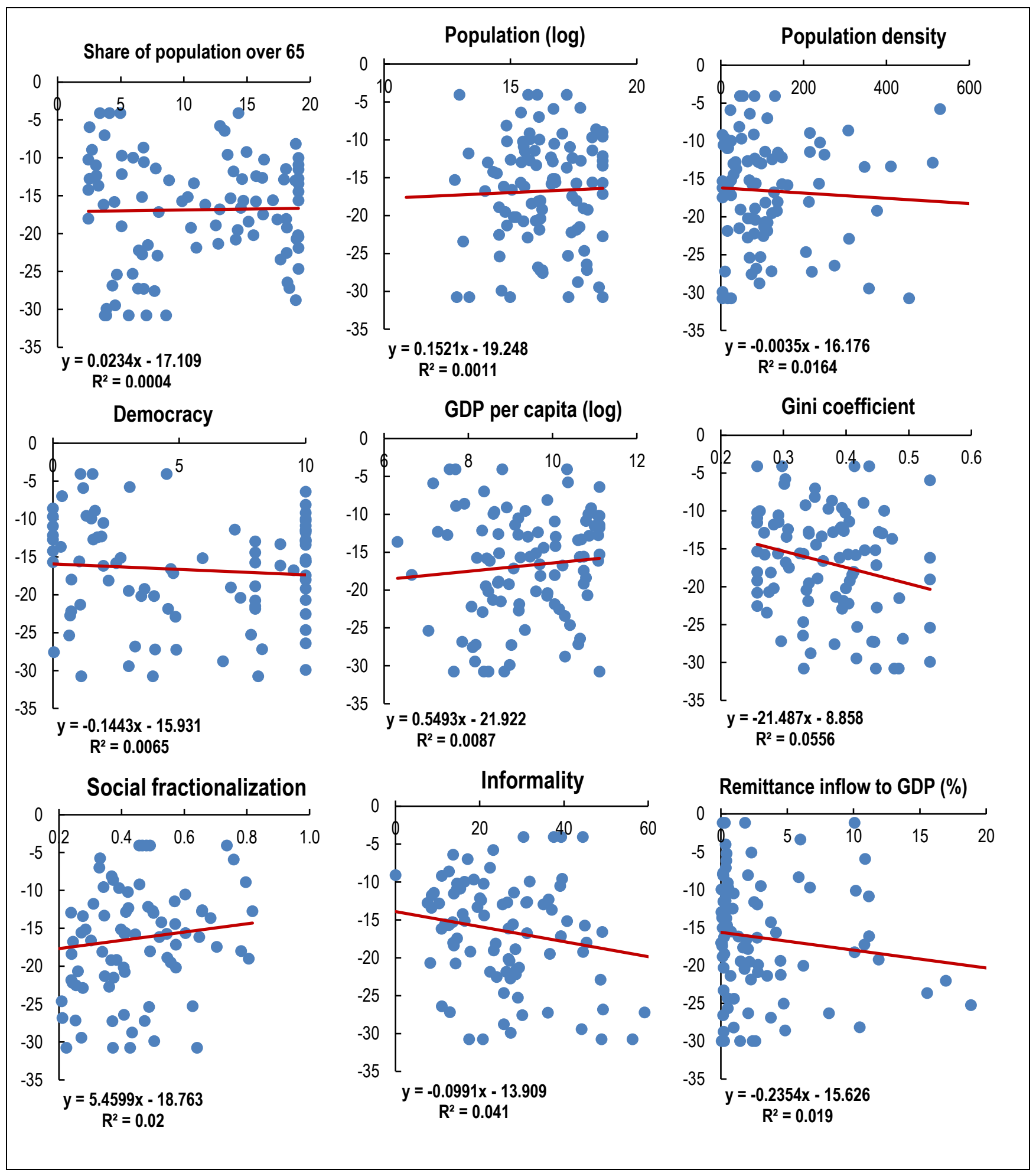

Note: Output performance is defined the difference between the observed cumulative real GDP growth in 2020H1 and the cumulative growth that was expected before the onset of the pandemic for the same period-based on the IMF World Economic Outlook 2020 January forecast for 2020H1. 
FIGURE 8. ROBUST DRIVERS OF OUTPUT PERFORMANCE ACROSS COUNTRIES, MAGNITUDE OF THE EFFECTS

Panel A. Output performance 1

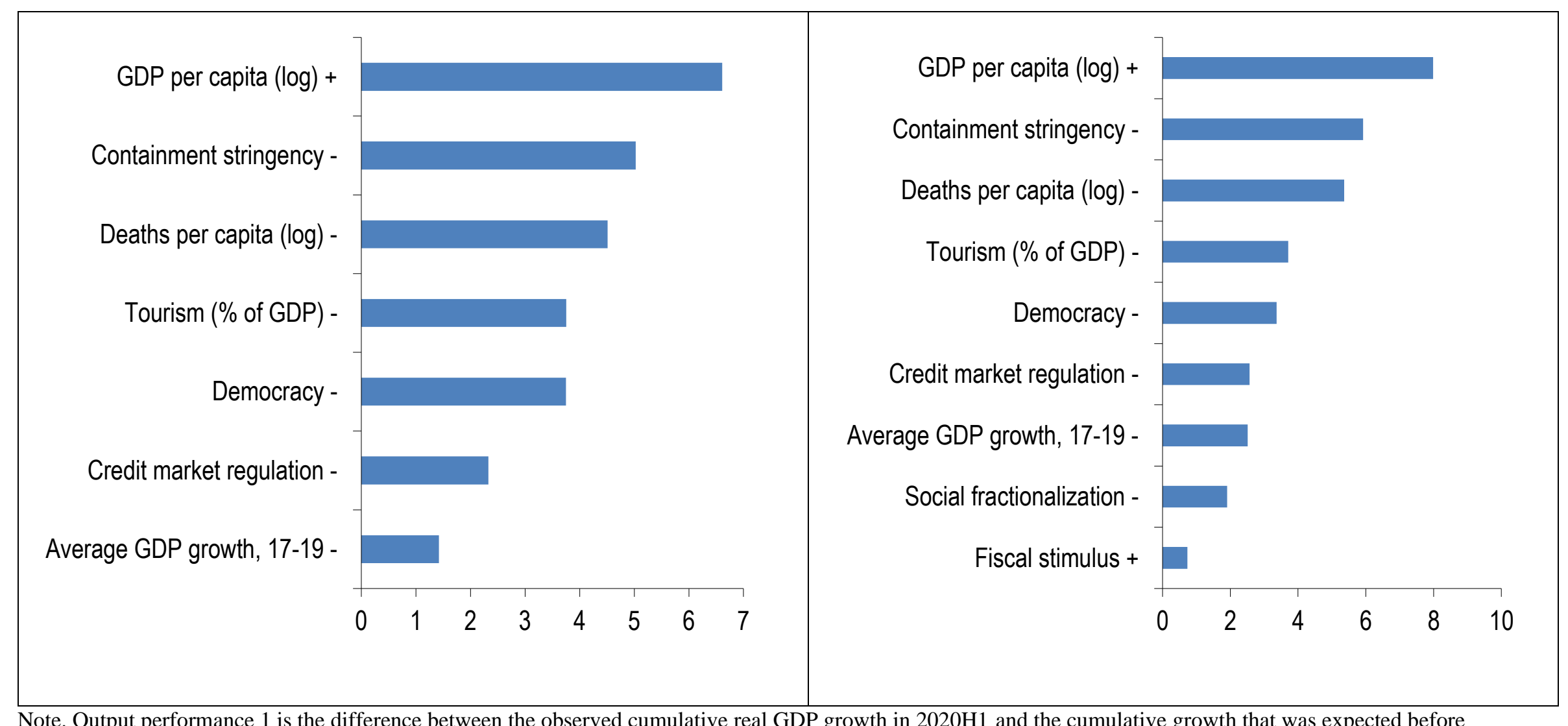

Note. Output performance 1 is the difference between the observed cumulative real GDP growth in $2020 \mathrm{H} 1$ and the cumulative growth that was expected before the onset of the pandemic for the same period — based on the IMF World Economic Outlook 2020 January forecast for 2020H1; Output performance 2 is the difference in cumulative real GDP growth between the first half of 2020 (2020H1) and the first half of 2019 (2019H1); The chart shows the differential effect on output performance moving the level of the variable from the $25^{\text {th }}$ percentile to the $75^{\text {th }}$ percentile of its distribution, based on the coefficients of the variables that are robust in column (I-II) of Table 7. - (+) denotes a negative (positive) effect on output. Estimates based on equation (1). 
TABLE 1. REgRESSION RESUlTS OF PUBLIC HEALTH, OLS AND WALS

\begin{tabular}{|c|c|c|c|c|}
\hline & \multicolumn{2}{|c|}{ Output performance 1} & \multicolumn{2}{|c|}{ Output performance 2} \\
\hline & OLS & WALS & OLS & WALS \\
\hline Deaths per capita (log) & $\begin{array}{c}-0.434 \\
(-0.895)\end{array}$ & $\begin{array}{c}-0.380 \\
(-0.974)\end{array}$ & $\begin{array}{c}-0.655 \\
(-1.076)\end{array}$ & $\begin{array}{c}\mathbf{- 0 . 4 9 6} \\
(-1.075)\end{array}$ \\
\hline Containment stringency & $\begin{array}{c}\mathbf{- 1 1 . 1 1 0} * * \\
(-2.756)\end{array}$ & $\begin{array}{l}\mathbf{- 8 . 4 2 8 *} \\
(-2.319)\end{array}$ & $\begin{array}{l}-10.041 \\
(-1.891)\end{array}$ & $\begin{array}{c}-7.460 \\
(-1.734)\end{array}$ \\
\hline Health condition & $\begin{array}{c}-1.011 \\
(-0.834)\end{array}$ & $\begin{array}{c}-0.602 \\
(-0.578)\end{array}$ & $\begin{array}{c}-1.080 \\
(-0.817)\end{array}$ & $\begin{array}{c}-0.639 \\
(-0.518)\end{array}$ \\
\hline $\mathrm{N}$ & 85 & 85 & 85 & 85 \\
\hline $\begin{array}{l}\text { Note: Output performance } 1 \\
\text { cumulative growth that was e } \\
\text { World Economic Outlook } 20 \\
\text { real GDP growth between the } \\
\text { parentheses. In bold those reg } \\
\text { greater than } 1 .{ }^{*} p<0.05, * * p\end{array}$ & $\begin{array}{l}\text { ce between the } \\
\text { re the onset of } t \\
\text { recast for } 2020 \\
2020(2020 \mathrm{H} 1) \\
\text { an be considere } \\
0.001 \text {. }\end{array}$ & $\begin{array}{l}\text { served cumu } \\
\text { pandemic fo } \\
\text { Output per } \\
\text { the first ha } \\
\text { robust"- th }\end{array}$ & $\begin{array}{l}\text { GDP growtl } \\
\text { period-ba } \\
\text { is the diffe } \\
\text { (2019H1). t- } \\
\text { a t-value in }\end{array}$ & $\begin{array}{l}20 \mathrm{H} 1 \text { and th } \\
\text { the IMF } \\
\text { cumulative } \\
\text { c reported in } \\
\text { e value }\end{array}$ \\
\hline
\end{tabular}

TABLE 2. REGRESSION RESULTS OF SECTORIAL COMPOSITION, OLS AND WALS

\begin{tabular}{|c|c|c|c|c|}
\hline & \multicolumn{2}{|c|}{ Output performance 1} & \multicolumn{2}{|c|}{ Output performance 2} \\
\hline & OLS & WALS & OLS & WALS \\
\hline Service & $\begin{array}{c}-0.126 \\
(-0.900)\end{array}$ & $\begin{array}{c}\mathbf{- 0 . 1 1 1} \\
(-1.064)\end{array}$ & $\begin{array}{c}-0.168 \\
(-1.081)\end{array}$ & $\begin{array}{c}\mathbf{- 0 . 1 4 8} \\
(-1.257)\end{array}$ \\
\hline Industry & $\begin{array}{c}0.052 \\
(0.481)\end{array}$ & $\begin{array}{c}0.064 \\
(0.561)\end{array}$ & $\begin{array}{c}0.074 \\
(0.607)\end{array}$ & $\begin{array}{c}0.091 \\
(0.710)\end{array}$ \\
\hline Tourism & $\begin{array}{c}-\mathbf{- 0 . 8 8 9} * * \\
(-3.083)\end{array}$ & $\begin{array}{c}-\mathbf{- 0 . 7 9 8} * * * * \\
(-7.632)\end{array}$ & $\begin{array}{c}-\mathbf{- 0 . 8 2 5} * * \\
(-2.912)\end{array}$ & $\begin{array}{c}-\mathbf{0 . 7 2 3} * * * \\
(-6.133)\end{array}$ \\
\hline $\mathrm{N}$ & 96 & 96 & 96 & 96 \\
\hline
\end{tabular}

Note: Output performance 1 is the difference between the observed cumulative real GDP growth in 2020H1 and the cumulative growth that was expected before the onset of the pandemic for the same period-based on the IMF World Economic Outlook 2020 January forecast for 2020H1; Output performance 2 is the difference in cumulative real GDP growth between the first half of $2020(2020 \mathrm{H} 1)$ and the first half of $2019(2019 \mathrm{H} 1)$. t-statistic reported in parentheses. In bold those regressors that can be considered "robust" - that is, with a t-value in absolute value greater than $1 . * \mathrm{p}<0.05, * * \mathrm{p}<0.01, * * * \mathrm{p}<0.001$. 
TABLE 3. REGRESSION RESULTS OF FISCAL AND MONETARY RESPONSE, OLS AND WALS

\begin{tabular}{|c|c|c|c|c|}
\hline & \multicolumn{2}{|c|}{ Output performance 1} & \multicolumn{2}{|c|}{ Output performance 2} \\
\hline & OLS & WALS & OLS & WALS \\
\hline Fiscal stimulus & $\begin{array}{c}-0.079 \\
(-0.486)\end{array}$ & $\begin{array}{c}-0.047 \\
(-0.364)\end{array}$ & $\begin{array}{c}-0.094 \\
(-0.586)\end{array}$ & $\begin{array}{c}-0.057 \\
(-0.416)\end{array}$ \\
\hline Liquidity & $\begin{array}{c}0.071 \\
(0.369)\end{array}$ & $\begin{array}{c}0.042 \\
(0.173)\end{array}$ & $\begin{array}{c}0.034 \\
(0.175)\end{array}$ & $\begin{array}{c}0.020 \\
(0.078)\end{array}$ \\
\hline Policy rate cut & $\begin{array}{c}0.002 \\
(0.322) \\
\end{array}$ & $\begin{array}{c}0.001 \\
(0.122) \\
\end{array}$ & $\begin{array}{c}0.008 \\
(0.896) \\
\end{array}$ & $\begin{array}{c}0.005 \\
(0.492)\end{array}$ \\
\hline $\mathrm{N}$ & 96 & 96 & 96 & 96 \\
\hline $\begin{array}{l}\text { Note: Output perfo } \\
\text { cumulative growth } \\
\text { World Economic } \mathrm{O} \\
\text { real GDP growth b } \\
\text { parentheses. In bol } \\
\text { greater than } 1 . * \text { p }\end{array}$ & $\begin{array}{l}\text { ce between th } \\
\text { re the onset o } \\
\text { recast for } 202 \\
2020(2020 \mathrm{H} \\
\text { an be conside } \\
<0.001 \text {. }\end{array}$ & $\begin{array}{l}\text { served cums } \\
\text { pandemic fo } \\
\text {; Output per } \\
\text { d the first ha } \\
\text { 'robust"- - th }\end{array}$ & $\begin{array}{l}\text { GDP growt } \\
\text { period-ba } \\
2 \text { is the diffe } \\
(2019 \mathrm{H} 1) \text {. } t \\
\text { a t-value in }\end{array}$ & $\begin{array}{l}20 \mathrm{H} 1 \text { and the } \\
\text { the IMF } \\
\text { n cumulative } \\
\text { c reported in } \\
\text { e value }\end{array}$ \\
\hline
\end{tabular}

TABLE 4. REGRESSION RESULTS OF REGULATION, OLS AND WALS

\begin{tabular}{|c|c|c|c|c|}
\hline & \multicolumn{2}{|c|}{ Output performance 1} & \multicolumn{2}{|c|}{ Output performance 2} \\
\hline & OLS & WALS & OLS & WALS \\
\hline Credit market regulation & $\begin{array}{c}-1.207 \\
(-1.707)\end{array}$ & $\begin{array}{c}\mathbf{- 0 . 7 9 8} \\
(-1.186)\end{array}$ & $\begin{array}{c}-1.840 \\
(-1.922)\end{array}$ & $\begin{array}{c}\mathbf{- 1 . 2 0 0} \\
(-1.509)\end{array}$ \\
\hline Labor market regulation & $\begin{array}{c}-0.057 \\
(-0.093)\end{array}$ & $\begin{array}{c}-0.025 \\
(-0.043)\end{array}$ & $\begin{array}{c}-0.307 \\
(-0.422)\end{array}$ & $\begin{array}{c}-0.162 \\
(-0.245)\end{array}$ \\
\hline Business regulation & $\begin{array}{c}1.297 \\
(1.457)\end{array}$ & $\begin{array}{c}\mathbf{0 . 8 2 0} \\
(1.141)\end{array}$ & $\begin{array}{c}0.632 \\
(0.583)\end{array}$ & $\begin{array}{c}0.398 \\
(0.483)\end{array}$ \\
\hline $\mathrm{N}$ & 94 & 94 & 94 & 94 \\
\hline
\end{tabular}

Note: Output performance 1 is the difference between the observed cumulative real GDP growth in 2020H1 and the cumulative growth that was expected before the onset of the pandemic for the same period-based on the IMF World Economic Outlook 2020 January forecast for 2020H1; Output performance 2 is the difference in cumulative real GDP growth between the first half of $2020(2020 \mathrm{H} 1)$ and the first half of 2019 (2019H1). t-statistic reported in parentheses. In bold those regressors that can be considered "robust" - that is, with a t-value in absolute value greater than $1 .{ }^{*} \mathrm{p}<0.05, * * \mathrm{p}<0.01, * * * \mathrm{p}<0.001$. 
TABLE 5. REGRESSION RESULTS OF MACROECONOMICS CHARACTERISTICS, OLS AND WALS

\begin{tabular}{|c|c|c|c|c|}
\hline & \multicolumn{2}{|c|}{ Output performance 1} & \multicolumn{2}{|c|}{ Output performance 2} \\
\hline & OLS & WALS & OLS & WALS \\
\hline Financial globalization & $\begin{array}{l}0.0266 \\
(0.238)\end{array}$ & $\begin{array}{l}0.0209 \\
(0.278)\end{array}$ & $\begin{array}{l}-0.0695 \\
(-0.552)\end{array}$ & $\begin{array}{l}-0.0430 \\
(-0.511)\end{array}$ \\
\hline Trade globalization & $\begin{array}{l}0.0601 \\
(0.875)\end{array}$ & $\begin{array}{c}0.0396 \\
(0.798)\end{array}$ & $\begin{array}{l}0.0707 \\
(0.963)\end{array}$ & $\begin{array}{l}0.0430 \\
(0.780)\end{array}$ \\
\hline Current account ( $\%$ of GDP) & $\begin{array}{l}0.0481 \\
(0.253)\end{array}$ & $\begin{array}{c}0.0248 \\
(0.158)\end{array}$ & $\begin{array}{l}0.0570 \\
(0.216)\end{array}$ & $\begin{array}{l}0.0410 \\
(0.243)\end{array}$ \\
\hline Financial system deposit (\% GDP) & $\begin{array}{l}-0.0235 \\
(-1.385)\end{array}$ & $\begin{array}{l}-0.0164 \\
(-0.995)\end{array}$ & $\begin{array}{l}-0.0154 \\
(-0.800)\end{array}$ & $\begin{array}{l}-0.0104 \\
(-0.599)\end{array}$ \\
\hline Government debt (\% of GDP) & $\begin{array}{l}-0.0362 \\
(-1.404)\end{array}$ & $\begin{array}{l}\mathbf{- 0 . 0 2 3 2} \\
(-1.115)\end{array}$ & $\begin{array}{l}-0.0384 \\
(-1.471)\end{array}$ & $\begin{array}{l}-\mathbf{0 . 0 2 4 8} \\
(-1.092)\end{array}$ \\
\hline Domestic credit (\% of GDP) & $\begin{array}{l}0.0224 \\
(1.042)\end{array}$ & $\begin{array}{c}0.0151 \\
(0.737)\end{array}$ & $\begin{array}{l}0.0243 \\
(1.028)\end{array}$ & $\begin{array}{l}0.0160 \\
(0.708)\end{array}$ \\
\hline Bank concentration & $\begin{array}{l}-0.0873 \\
(-1.369)\end{array}$ & $\begin{array}{l}\mathbf{- 0 . 0 6 0 1} \\
(-1.092)\end{array}$ & $\begin{array}{l}-0.0744 \\
(-1.113)\end{array}$ & $\begin{array}{l}-0.0489 \\
(-0.838)\end{array}$ \\
\hline Exchange rate regime & $\begin{array}{c}-0.231 \\
(-0.160)\end{array}$ & $\begin{array}{c}-0.157 \\
(-0.117)\end{array}$ & $\begin{array}{c}0.262 \\
(0.172)\end{array}$ & $\begin{array}{c}0.192 \\
(0.129)\end{array}$ \\
\hline Average GDP growth (17-19) & $\begin{array}{l}\mathbf{- 1 . 0 5 5} * \\
(-1.682)\end{array}$ & $\begin{array}{c}\mathbf{- 0 . 6 7 7} \\
(-1.444)\end{array}$ & $\begin{array}{c}\mathbf{- 1 . 7 4 0} * * \\
(-2.369)\end{array}$ & $\begin{array}{c}\mathbf{- 1 . 1 2 4} * * \\
(-2.172)\end{array}$ \\
\hline $\mathrm{N}$ & 70 & 70 & 70 & 70 \\
\hline $\begin{array}{l}\text { Note: Output performance } 1 \text { is the diffe } \\
\text { cumulative growth that was expected be } \\
\text { World Economic Outlook } 2020 \text { January } \\
\text { real GDP growth between the first half } \\
\text { parentheses. In bold those regressors th } \\
\text { greater than } 1 . * p<0.05, * * p<0.01 \text {, ** }\end{array}$ & $\begin{array}{l}\text { e between th } \\
\text { e the onset of } \\
\text { ecast for } 202 \\
020(2020 \mathrm{H} 1 \\
\text { an be conside } \\
0.001 \text {. }\end{array}$ & $\begin{array}{l}\text { served cum } \\
\text { pandemic fo } \\
\text { Output per } \\
\text { the first ha } \\
\text { robust"- th }\end{array}$ & $\begin{array}{l}\text { GDP growtl } \\
\text { period-bas } \\
2 \text { is the differ } \\
\text { (2019H1). t- } \\
\text { a t-value in }\end{array}$ & $\begin{array}{l}20 \mathrm{H} 1 \text { and the } \\
\text { the IMF } \\
\text { a cumulative } \\
\text { c reported in } \\
\text { e value }\end{array}$ \\
\hline
\end{tabular}


TABLE 6. REGRESSION RESULTS OF DEVELOPMENT, DEMOGRAPHIC AND INSTITUTIONS, OLS AND WALS

\begin{tabular}{|c|c|c|c|c|}
\hline & \multicolumn{2}{|c|}{ Output performance 1} & \multicolumn{2}{|c|}{ Output performance 2} \\
\hline & OLS & WALS & OLS & WALS \\
\hline Share of population over 65 & $\begin{array}{c}-0.182 \\
(-0.847)\end{array}$ & $\begin{array}{c}-0.107 \\
(-0.511)\end{array}$ & $\begin{array}{c}-0.333 \\
(-1.213)\end{array}$ & $\begin{array}{c}-0.218 \\
(-0.887)\end{array}$ \\
\hline Population (log) & $\begin{array}{c}-0.0445 \\
(-0.0668)\end{array}$ & $\begin{array}{c}-0.0472 \\
(-0.0862)\end{array}$ & $\begin{array}{c}-0.107 \\
(-0.129)\end{array}$ & $\begin{array}{c}-0.126 \\
(-0.193)\end{array}$ \\
\hline GDP per capita $(\log )$ & $\begin{array}{c}-0.381 \\
(-0.185)\end{array}$ & $\begin{array}{c}-0.290 \\
(-0.235)\end{array}$ & $\begin{array}{c}-0.479 \\
(-0.222)\end{array}$ & $\begin{array}{c}-0.330 \\
(-0.222)\end{array}$ \\
\hline Democracy & $\begin{array}{c}-0.254 \\
(-0.567)\end{array}$ & $\begin{array}{c}-0.228 \\
(-0.771)\end{array}$ & $\begin{array}{c}-0.283 \\
(-0.578)\end{array}$ & $\begin{array}{c}-0.198 \\
(-0.569)\end{array}$ \\
\hline Population density & $\begin{array}{c}-0.00463 \\
(-0.619)\end{array}$ & $\begin{array}{c}-0.00361 \\
(-0.567)\end{array}$ & $\begin{array}{c}-0.00626 \\
(-0.748)\end{array}$ & $\begin{array}{c}-0.00382 \\
(-0.494)\end{array}$ \\
\hline Gini coefficient & $\begin{array}{c}-\mathbf{4 1 . 4 0 * *} \\
(-2.569)\end{array}$ & $\begin{array}{c}-29.44 * * \\
(-2.113)\end{array}$ & $\begin{array}{c}-28.36 \\
(-1.354)\end{array}$ & $\begin{array}{c}\mathbf{- 1 8 . 0 8} \\
(-1.127)\end{array}$ \\
\hline Social fractionalization & $\begin{array}{c}\mathbf{1 0 . 4 5} * * \\
(2.114)\end{array}$ & $\begin{array}{l}7.895 * \\
(1.792)\end{array}$ & $\begin{array}{c}6.586 \\
(1.082)\end{array}$ & $\begin{array}{c}4.540 \\
(0.873)\end{array}$ \\
\hline Informality & $\begin{array}{c}-0.158 \\
(-1.388)\end{array}$ & $\begin{array}{c}\mathbf{- 0 . 1 1 7} \\
(-1.599)\end{array}$ & $\begin{array}{c}-0.166 \\
(-1.355)\end{array}$ & $\begin{array}{c}\mathbf{- 0 . 1 1 8} \\
(-1.369)\end{array}$ \\
\hline Remittance to GDP (\%) & $\begin{array}{c}0.0132 \\
(0.0590) \\
\end{array}$ & $\begin{array}{r}0.0302 \\
(0.144) \\
\end{array}$ & $\begin{array}{c}-0.126 \\
(-0.472)\end{array}$ & $\begin{array}{l}-0.0624 \\
(-0.244)\end{array}$ \\
\hline & 85 & 85 & 85 & 85 \\
\hline
\end{tabular}

Note: Output performance 1 is the difference between the observed cumulative real GDP growth in $2020 \mathrm{H} 1$ and the cumulative growth that was expected before the onset of the pandemic for the same period-based on the IMF World Economic Outlook 2020 January forecast for 2020H1; Output performance 2 is the difference in cumulative real GDP growth between the first half of $2020(2020 \mathrm{H} 1)$ and the first half of 2019 (2019H1). t-statistic reported in parentheses. In bold those regressors that can be considered "robust" - that is, with a t-value in absolute value greater than $1 . * \mathrm{p}<0.05, * * \mathrm{p}<0.01, * * * \mathrm{p}<0.001$. 
TABLE 7. ROBUST DRIVERS OF OUTPUT PERFORMANCE ACROSS COUNTRIES-WALS

Output performance 1

Output performance 2

Health condition

0.41

0.27

Containment stringency

$-2.23$

$-2.38$

Deaths per capita (log)

$-2.44$

$-2.65$

Liquidity

$-0.81$

$-0.84$

Policy rate cut

0.37

0.48

Fiscal stimulus

0.85

1.20

Labor market regulation

$-0.07$

$-0.02$

Credit market regulation

$-1.59$

$-1.63$

Business regulation

$-0.28$

$-0.40$

Financial globalization

0.75

0.66

Trade globalization

$-0.28$

$-0.36$

Current account (\% of GDP)

$-0.88$

$-0.78$

Financial system deposit (\% of GDP)

$-0.83$

$-0.47$

Government debt (\% of GDP)

$-0.92$

$-0.95$

Domestic credit (\% of GDP)

$-0.05$

$-0.29$

Bank concentration

0.19

0.46

Exchange rate regime

$-0.93$

$-0.60$

Average GDP growth, 17-19

$-1.05$

$-1.71$

Tourism (\% of GDP)

$-3.01$

$-2.75$

Service (\% of GDP)

$-0.10$

$-0.40$

Industry (\% of GDP)

$-0.28$

$-0.55$

Share of population over 65

$-0.29$

$-0.79$

Population $(\log )$

$-0.20$

0.03

GDP per capita (log)

1.14

1.24

Democracy

$-1.67$

$-1.38$

Population density

0.50

0.54

Gini coefficient

0.65

0.86

Social fractionalization

$-0.71$

$-1.25$

Informality

0.23

0.32

Remittance inflow to GDP (\%)

0.31

0.5

$\mathrm{N}$ 60

Note: t-statistic reported in the table. In bold those regressors that can be considered "robust". Estimates based on equation (1). 
TABLE 8. ROBUST DRIVERS OF OUTPUT PERFORMANCE ACROSS COUNTRIES — CONTROLLING FOR OUTLIERS

\section{Output performance 1}

Output performance 2

Health condition

0.42

0.22

Containment stringency

$-2.11$

$-1.89$

Deaths per capita $(\log )$

$-2.45$

$-2.74$

Liquidity

$-0.56$

$-0.62$

Policy rate cut

0.83

0.98

Fiscal stimulus

$\mathbf{1 . 0 5}$

1.20

Labor market regulation

0.38

0.24

Credit market regulation

$-1.72$

$-1.87$

Business regulation

0.03

0.04

Financial globalization

0.67

0.42

Trade globalization

$-0.47$

$-0.33$

Current account (\% of GDP)

$-0.76$

$-0.96$

Financial system deposit (\% of GDP)

$-0.63$

$-0.20$

Government debt (\% of GDP)

$-0.97$

$-1.10$

Domestic credit (\% of GDP)

$-0.07$

$-0.37$

Bank concentration

0.42

0.67

Exchange rate regime

$-0.92$

$-0.70$

Average GDP growth, 17-19

$-1.24$

$-1.90$

Tourism (\% of GDP)

$-3.24$

$-2.73$

Service (\% of GDP)

$-0.19$

$-0.38$

Industry (\% of GDP)

$-0.13$

$-0.38$

Share of population over 65

$-0.34$

$-0.78$

Population (log)

$-0.59$

$-0.16$

GDP per capita (log)

1.08

1.31

Democracy

$-1.95$

$-1.37$

Population density

0.63

0.56

Gini coefficient

0.55

0.67

Social fractionalization

$-0.86$

$-1.29$

Informality

0.30

0.44

Remittance inflow to GDP (\%)

0.05

0.20

$\mathrm{N}$

60

Note: t-statistic reported in the table. In bold those regressors that can be considered "robust". Estimates based on equation (1). 
TABLE 9. ROBUST DRIVERS OF OUTPUT PERFORMANCE ACROSS COUNTRIES-BMA

Output performance 1

Output performance 2

Tourism (\% of GDP) (-)

0.99

0.85

Containment stringency (-)

0.97

0.88

Deaths per capita (log) (-)

0.56

0.54

Government debt (\% of GDP) (-)

0.17

0.17

Democracy (-)

0.14

0.08

GDP per capita $(\log )(+)$

0.11

0.1

Share of population over $65(-)$

0.1

0.35

Fiscal stimulus (+)

0.08

0.08

Credit market regulation (-)

0.07

0.11

Trade globalization (-)

0.07

0.09

Domestic credit (\% of GDP) (+)

0.07

0.09

Exchange rate regime (-)

0.07

0.05

Average GDP growth, 17-19 (-)

0.07

0.32

Population (log) (-)

0.07

0.06

Business regulation (+)

0.06

0.06

Financial system deposit (\% of GDP) (-)

0.06

0.04

Remittance inflow to GDP (\%) (-)

0.06

0.06

Informality (-)

0.06

0.05

Health condition (-)

0.05

0.05

Policy rate cut $(+)$

0.05

0.06

Financial globalization (-)

0.05

0.06

Service (\% of GDP) (-)

0.05

0.06

Industry (\% of GDP) (+)

0.05

0.05

Population density (-)

0.05

0.04

Gini coefficient (-)

0.05

0.06

Social fractionalization (-)

0.05

0.05

Liquidity (+)

0.04

0.04

Labor market regulation (+)

0.04

0.05

Current account (\% of GDP) (-)

0.04

0.05

Bank concentration (+)

0.04

0.05

60

60

Note: posterior-inclusion-probability reported in the table. In bold those regressors with a posterior inclusion probability above 0.50 ; in italic those with a posterior inclusion probability above 0.1 . Estimates based on equation (1). - (+) denotes a negative (positive) effect on output. 
TABLE 10. ROBUST DRIVERS OF OUTPUT PERFORMANCE ACROSS COUNTRIES-ADDITIONAL COVARIATES

Output performance 1

Output performance 2

Health condition

0.11

0.10

Containment stringency

$-1.59$

$-1.90$

Deaths per capita (log)

$-2.56$

$-2.65$

Liquidity

0.10

$-0.12$

Policy rate cut

$-0.02$

$-0.17$

Fiscal stimulus

2.18

1.79

Labor market regulation

$-0.75$

$-0.39$

Credit market regulation

$\mathbf{- 1 . 8 8}$

$-2.09$

Business regulation

0.42

0.09

Financial globalization

1.08

0.87

Trade globalization

$-0.49$

$-0.33$

Current account (\% of GDP)

$-0.96$

$-1.16$

Financial system deposit (\% of GDP)

0.88

0.41

Government debt (\% of GDP)

$\mathbf{- 1 . 9 6}$

$-2.10$

Domestic credit (\% of GDP)

$-0.02$

0.37

Bank concentration

0.44

0.58

Exchange rate regime

$-0.72$

$-0.32$

Average GDP growth, 17-19

$-1.92$

$-2.49$

Tourism (\% of GDP)

$-1.45$

$-0.75$

Service (\% of GDP)

0.53

0.15

Industry (\% of GDP)

0.41

0.00

Share of population over 65

0.04

$-0.75$

Population (log)

$-0.94$

GDP per capita (log)

1.49

$-0.50$

Democracy

0.03

1.64

Population density

0.50

0.55

Gini coefficient

$-0.61$

0.69

Social fractionalization

$-1.28$

$-0.58$

Informality

$-1.94$

$-1.28$

Remittance inflow to GDP (\%)

$-0.24$

$-1.47$

Rule of law

$-2.01$

$-0.13$

Average tariff rates

$-1.73$

$-1.82$

Normalized current account index

0.25

$-1.18$

Non-performing loan

0.04

0.63

Poverty rate

0.99

0.15

Reserve (\% of imports)

$-0.72$

0.59

$\mathrm{N}$

48

0.63

Note: t-statistic reported in the table. In bold those regressors that can be considered "robust". Estimates based on equation (1). 
TABLE 11. ROBUST DRIVERS OF OUTPUT PERFORMANCE ACROSS COUNTRIES — USING ONLY Q2 DATA

\section{Output performance 1}

Health condition

Containment stringency

Deaths per capita $(\log )$

Liquidity

Policy rate cut

Fiscal stimulus

Labor market regulation

Credit market regulation

Business regulation

Financial globalization

Trade globalization

Current account (\% of GDP)

Financial system deposit (\% of GDP)

Government debt (\% of GDP)

Domestic credit (\% of GDP)

Bank concentration

Exchange rate regime

Average GDP growth, 17-19

Tourism (\% of GDP)

Service (\% of GDP)

Industry (\% of GDP)

Share of population over 65

Population $(\log )$

GDP per capita (log)

Democracy

Population density

Gini coefficient

Social fractionalization

Informality

Remittance inflow to GDP (\%)
$-0.07$

$-1.80$

$-2.89$

$-0.69$

0.00

0.68

$-0.79$

$-1.98$

$-0.05$

0.69

$-0.11$

$-1.01$

$-0.97$

$-1.08$

$-0.02$

0.56

$-1.19$

$-1.00$

$-2.69$

0.53

0.40

$-0.09$

0.26

1.17

$-1.61$

0.26

0.00

$-0.02$

$-0.10$

0.58

$\mathrm{N} \quad 60 \quad 60$

Output performance 2

$-0.19$

$-1.71$

$-3.20$

$-0.63$

0.08

1.01

$-0.85$

$-2.04$

0.01

0.46

$-0.06$

$-1.04$

$-0.90$

$-1.20$

$-0.21$

0.71

$-1.14$

$-1.49$

$-2.48$

0.54

0.40

$-0.24$

0.35

1.18

$-1.40$

0.30

$-0.03$

$-0.30$

$-0.06$

0.54 equation (1). 
TABLE 12. ROBUST DRIVERS OF OUTPUT PERFORMANCE ACROSS COUNTRIES-INTERACTION WITH INCOME LEVEL

Continuous Dummy 1 Dummy 2

\begin{tabular}{|c|c|c|c|c|c|c|}
\hline & OP1 & OP2 & OP1 & OP2 & OP1 & OP2 \\
\hline \multicolumn{7}{|l|}{ Covariates } \\
\hline Health condition & 0.15 & -0.06 & 0.07 & 0.00 & 0.30 & 0.15 \\
\hline Containment stringency & -1.66 & -1.22 & -1.00 & -1.60 & -1.62 & -1.93 \\
\hline Deaths per capita (log) & -1.78 & -2.54 & -2.71 & -2.63 & -2.26 & -2.49 \\
\hline Liquidity & -1.88 & -2.06 & -0.46 & -0.59 & -1.25 & -1.31 \\
\hline Policy rate cut & -0.72 & -0.73 & 0.22 & -0.23 & 0.53 & 0.65 \\
\hline Fiscal stimulus & 0.29 & 0.91 & -1.19 & -0.56 & 0.31 & 0.66 \\
\hline Labor market regulation & -0.30 & -0.03 & -0.46 & -0.47 & -0.23 & -0.23 \\
\hline Credit market regulation & -1.94 & -1.97 & -1.25 & -1.18 & -1.97 & -1.97 \\
\hline Business regulation & 0.13 & 0.09 & -0.51 & -0.47 & -0.15 & -0.19 \\
\hline Financial globalization & -0.01 & -0.58 & 0.65 & 0.55 & 0.39 & 0.24 \\
\hline Trade globalization & -0.59 & -1.00 & 0.25 & -0.18 & -0.13 & -0.35 \\
\hline Current account (\% of GDP) & -0.08 & 0.13 & -0.20 & -0.21 & -0.62 & -0.54 \\
\hline Financial system deposit (\% of GDP) & -0.45 & 0.00 & -1.15 & -0.71 & -0.30 & 0.19 \\
\hline Government debt (\% of GDP) & -0.42 & -0.42 & -0.49 & -0.59 & -0.53 & -0.59 \\
\hline Domestic credit (\% of GDP) & -0.05 & -0.05 & 0.15 & 0.05 & -0.34 & -0.55 \\
\hline Bank concentration & 0.18 & 0.51 & -0.06 & 0.11 & 0.53 & 0.88 \\
\hline Exchange rate regime & -0.49 & 0.12 & -0.22 & -0.07 & -0.94 & -0.59 \\
\hline Average GDP growth, 17-19 & -0.95 & -1.49 & -0.37 & -0.83 & -0.98 & -1.54 \\
\hline Tourism (\% of GDP) & -3.21 & -3.21 & -3.24 & -2.94 & -3.02 & -2.84 \\
\hline Service (\% of GDP) & 0.09 & -0.46 & 0.80 & 0.15 & 0.23 & -0.09 \\
\hline Industry (\% of GDP) & 0.31 & 0.02 & 0.57 & -0.13 & 0.28 & 0.03 \\
\hline Share of population over 65 & 0.24 & -0.38 & 0.44 & -0.01 & -0.20 & -0.75 \\
\hline Population (log) & -0.67 & -0.62 & -0.95 & -0.58 & -0.38 & -0.19 \\
\hline GDP per capita (log) & 1.54 & 2.27 & 1.64 & 1.57 & 1.05 & 1.20 \\
\hline Democracy & -1.08 & -0.64 & -1.76 & -0.93 & -1.52 & -1.31 \\
\hline Population density & -0.02 & -0.31 & 0.08 & 0.32 & 0.04 & 0.02 \\
\hline Gini coefficient & 0.63 & 0.68 & 1.26 & 1.23 & 0.64 & 0.77 \\
\hline Social fractionalization & 0.13 & -0.19 & -0.35 & -0.74 & -0.21 & -0.55 \\
\hline Informality & -0.06 & -0.12 & -0.12 & 0.12 & -0.07 & -0.03 \\
\hline Remittance inflow to GDP (\%) & 1.15 & 1.95 & 0.10 & 0.63 & 0.42 & 0.74 \\
\hline Containment*Income level & 1.01 & 1.00 & 0.21 & 0.57 & 0.42 & 0.75 \\
\hline Deaths per capita*Income level & 1.44 & 2.18 & 1.53 & 1.39 & 0.39 & 0.57 \\
\hline Liquidity*Income level & 1.84 & 2.01 & 0.43 & 0.52 & 1.40 & 1.47 \\
\hline Policy rate cut*Income level & 0.77 & 0.79 & 0.73 & 1.10 & 0.35 & 0.30 \\
\hline Fiscal stimulus*Income level & -0.29 & -0.90 & 1.22 & 0.60 & -0.15 & -0.45 \\
\hline $\mathrm{N}$ & 60 & 60 & 60 & 60 & 60 & 60 \\
\hline
\end{tabular}

Note: t-statistic reported in the table. In bold those regressors that can be considered robust". Estimates bases on equation (1). Dummy 1 uses the average of GDP per capita as reference, 1 denotes above average, otherwise 0; Dummy 2 uses the definition of income level in the World Economic Outlook, 1 is advanced economies, otherwise 0; OP stands for output performance. 
ANNEX A

Table A1. Sources and descriptive statistics of the variables used in the analysis

\begin{tabular}{|c|c|c|c|c|c|}
\hline Category & Description & Source & Obs & Mean & Std. dev \\
\hline $\begin{array}{l}\text { Measure of output } \\
\text { performance }\end{array}$ & Output performance 1 & $\mathrm{IMF}$ & 97 & -17.60 & 12.44 \\
\hline \multirow[t]{2}{*}{ Health factors } & Health condition & $\mathrm{JHU}$ & 191 & 40.58 & 14.41 \\
\hline & Containment stringency & OxCGRT & 183 & 0.59 & 0.20 \\
\hline \multirow[t]{3}{*}{ Policy Support } & Liquidity & IMF & 194 & 1.25 & 3.50 \\
\hline & Policy rate cut & $\mathrm{IMF}$ & 194 & 87.29 & 134.04 \\
\hline & Fiscal stimulus & IMF & 194 & 4.26 & 6.09 \\
\hline Regulation & Labor market regulation & FI & 157 & 6.46 & 1.36 \\
\hline \multirow[t]{6}{*}{ Macroeconomics factors } & Financial globalization & $\mathrm{KOF}$ & 180 & 63.19 & 19.67 \\
\hline & Trade globalization & $\mathrm{KOF}$ & 183 & 56.41 & 20.37 \\
\hline & Current account ( $\%$ of GDP) & IMF & 132 & -1.72 & 8.36 \\
\hline & Financial system deposit (\% of GDP) & FSD & 163 & 59.93 & 50.73 \\
\hline & Government debt (\% of GDP) & FSD & 115 & 56.34 & 37.13 \\
\hline & Domestic credit (\% of GDP) & FSD & 165 & 57.31 & 43.31 \\
\hline
\end{tabular}




\begin{tabular}{|c|c|c|c|c|c|}
\hline & Exchange rate regime & IMF & 192 & 2.07 & 0.87 \\
\hline \multirow[t]{2}{*}{ Sectorial composition } & Tourism (\% of GDP) & WTTC & 174 & 13.96 & 13.07 \\
\hline & Service (\% of GDP) & WDI & 193 & 56.60 & 13.36 \\
\hline \multirow[t]{7}{*}{ Development and others } & Share of population over 65 & WDI & 190 & 8.34 & 5.88 \\
\hline & Population (log) & WDI & 211 & 15.29 & 2.41 \\
\hline & GDP per capita (log) & WDI & 208 & 8.83 & 1.50 \\
\hline & Democratization & Polity IV & 152 & 3.87 & 3.92 \\
\hline & Social fractionalization & $\begin{array}{l}\text { Alesina et al. } \\
(2003)\end{array}$ & 179 & 0.44 & 0.19 \\
\hline & Informality & WDI & 143 & 29.30 & 14.25 \\
\hline & Remittance inflow to GDP (\%) & FSD & 180 & 4.68 & 6.61 \\
\hline
\end{tabular}

Notes: Output performance 1 is the difference between the observed cumulative real GDP growth in $2020 \mathrm{H} 1$ and the cumulative growth that was expected before the onset of the pandemic for the same period — based on the IMF World Economic Outlook 2020 January forecast for 2020H1; Output performance 2 is the difference in cumulative real GDP growth between the first half of 2020 (2020H1) and the first half of 2019 (2019H1);. IMF is International Monetary Fund; JHU is Johns Hopkins University Coronavirus Resource Center; OxCGRT is Oxford COVID-19 Government Response Tracker; FI is Fraser Institute Economic Freedom Network; KOF is Swiss Economic Institute; FSD is World Bank Financial Structure Database; WDI is World Development Indicators; WTTC is World Tourist \& Tourism Council. 
Figure A1. Output performances (\%) and public health

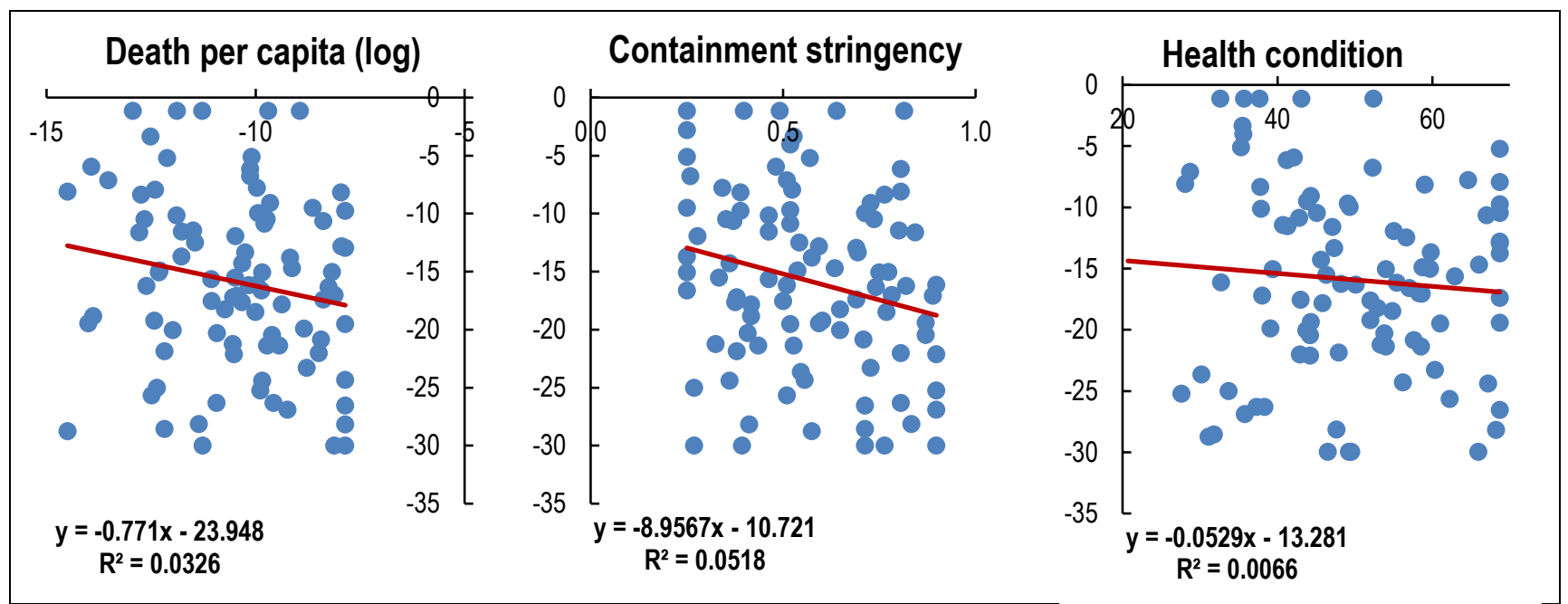

Note: Output performance is defined as the difference in cumulative real GDP growth between the first half of 2020 (2020H1) and the first half of 2019 (2019H1).

Figure A2. Output performances (\%) and sectoral composition

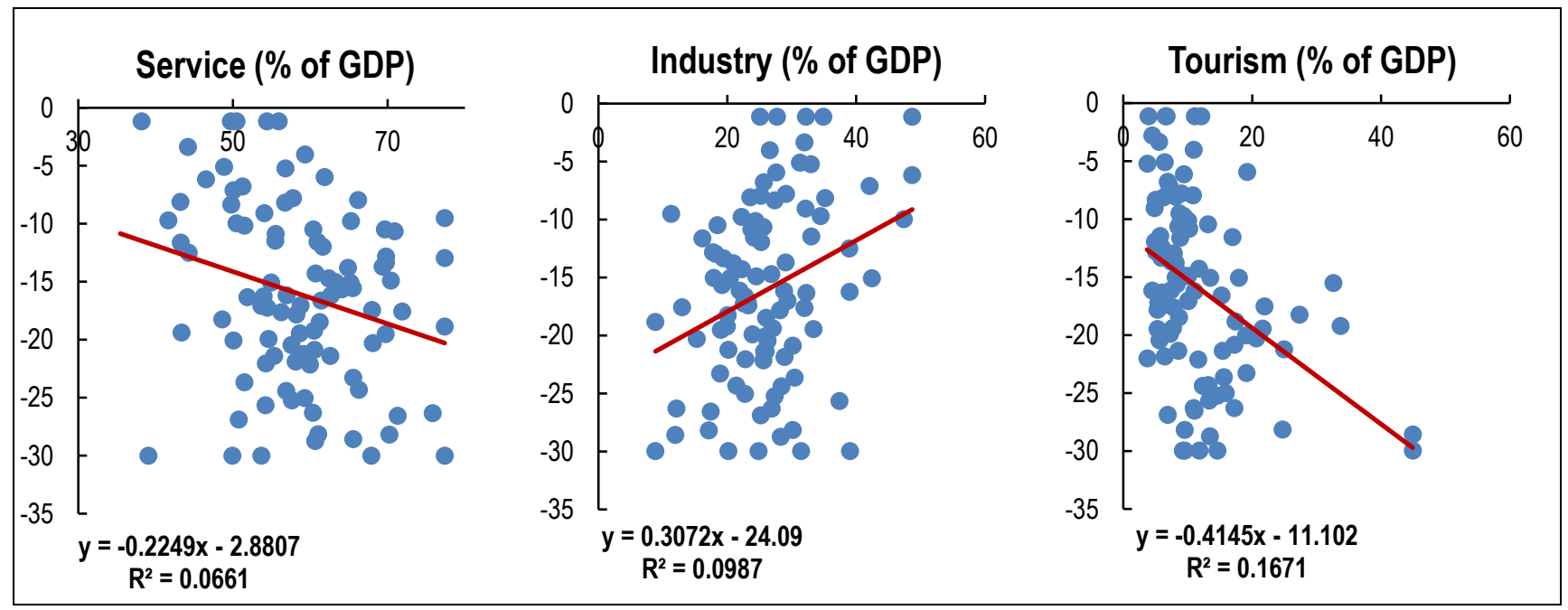

Note: Output performance is defined as the difference in cumulative real GDP growth between the first half of 2020 (2020H1) and the first half of 2019 (2019H1). 
Figure A3. Output performances (\%) and fiscal and monetary response

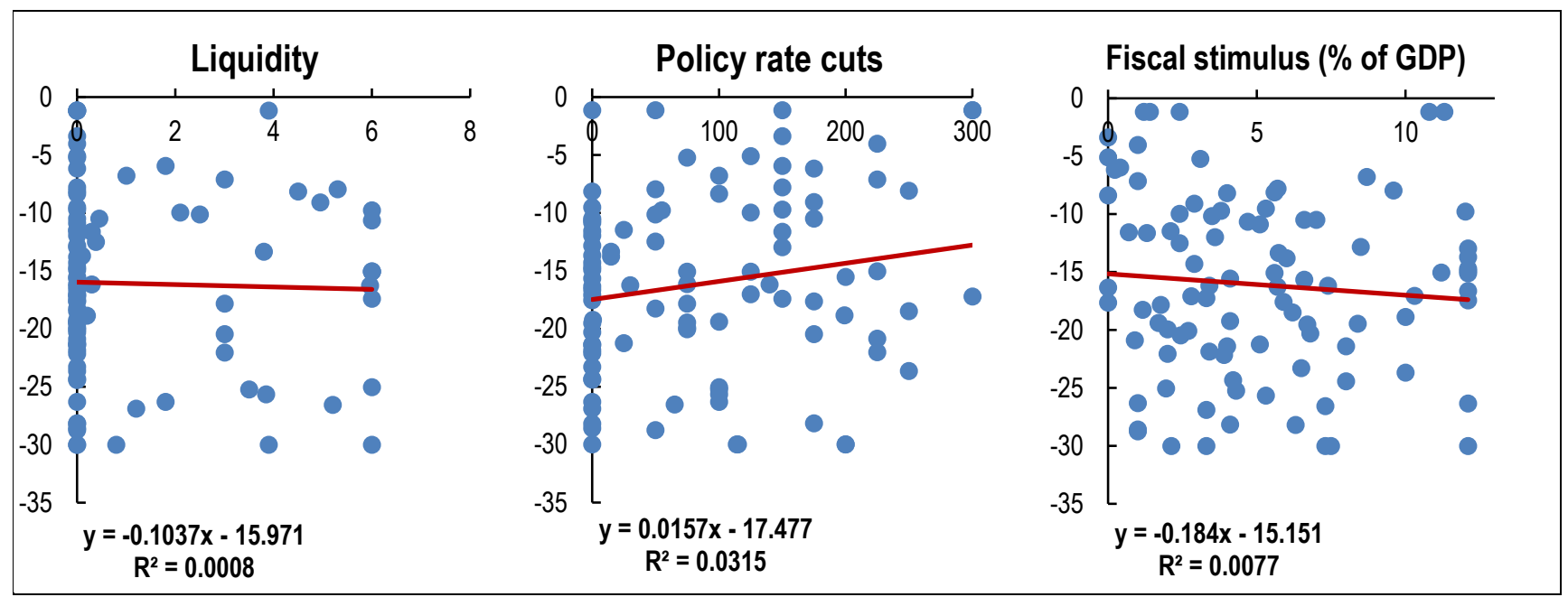

Note: Output performance is defined as the difference in cumulative real GDP growth between the first half of 2020 (2020H1) and the first half of 2019 (2019H1).

Figure A4. Output performances (\%) and regulation

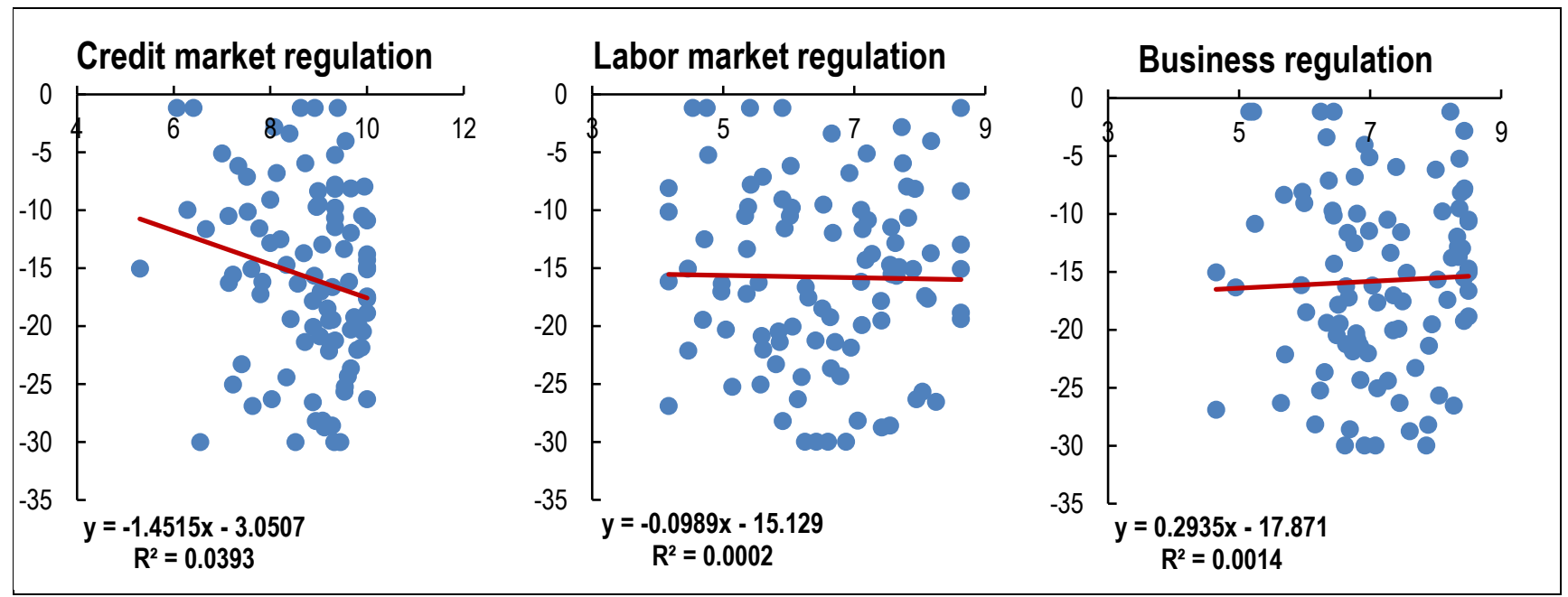

Note: Output performance is defined as the difference in cumulative real GDP growth between the first half of 2020 $(2020 \mathrm{H} 1)$ and the first half of $2019(2019 \mathrm{H} 1)$. 
Figure A5. Output performances (\%) and macroeconomics characteristics
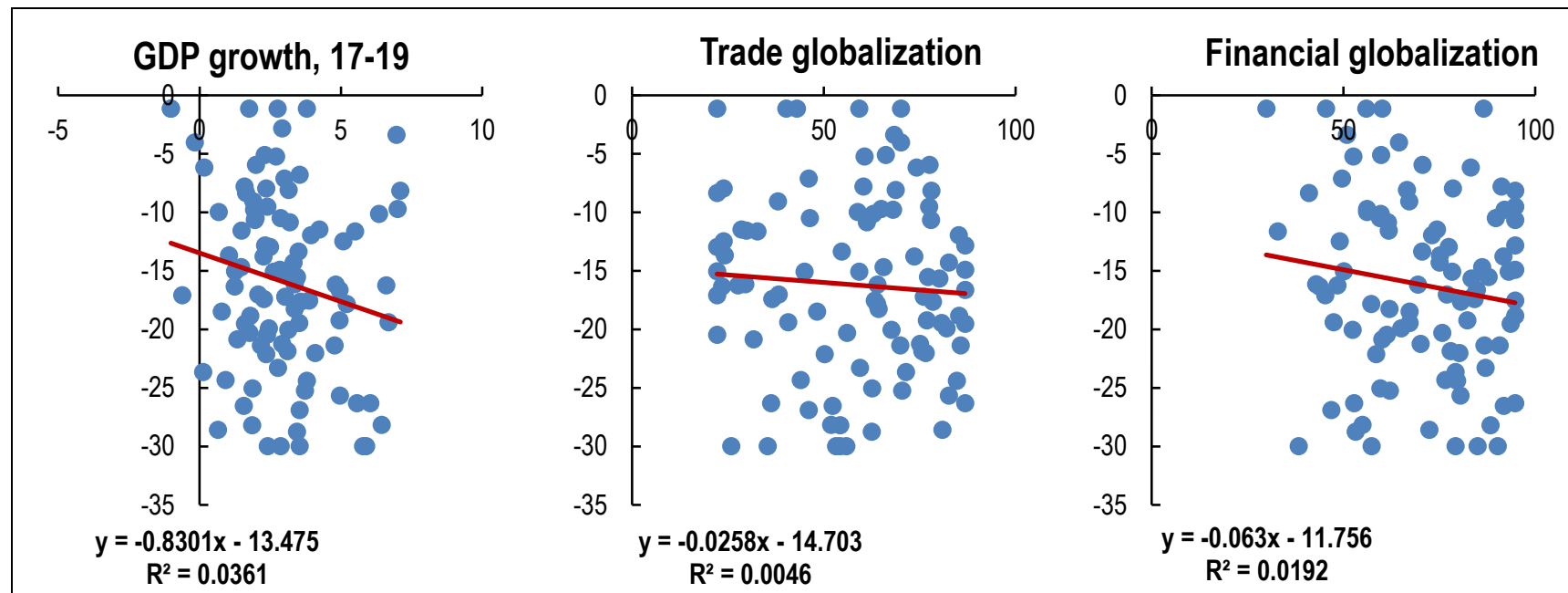

Financial system deposit
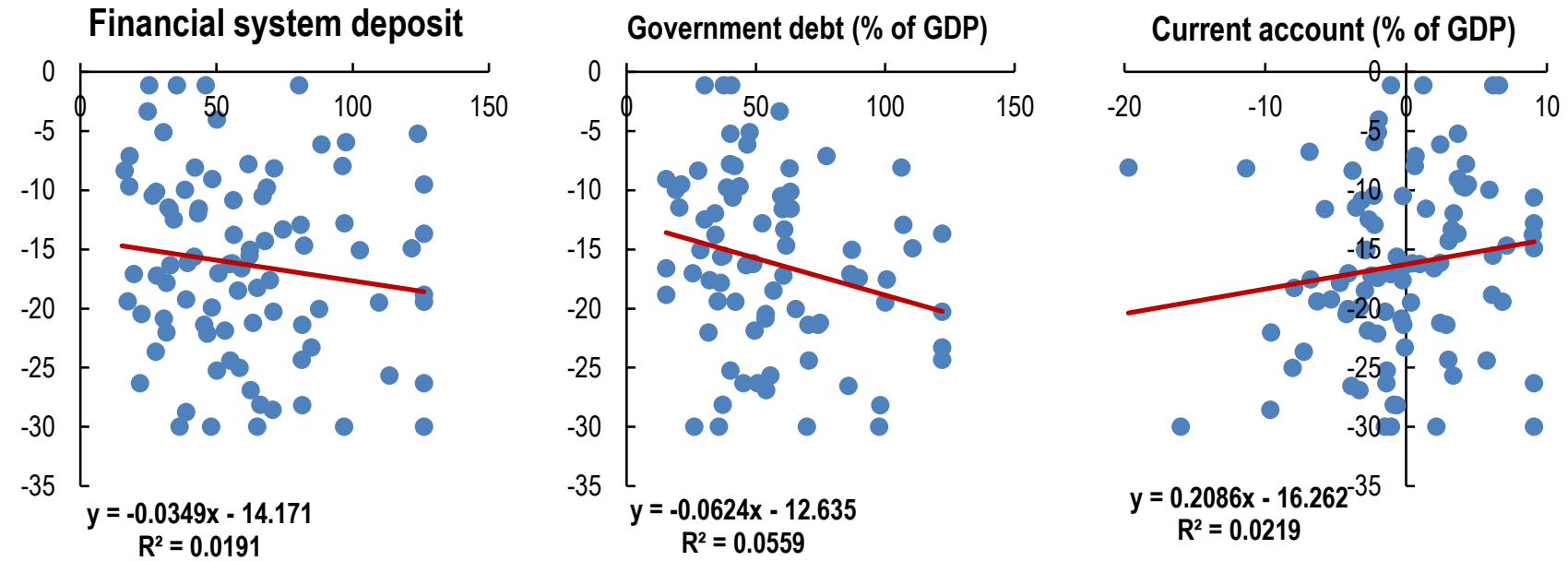

Domestic credit (\% of GDP)
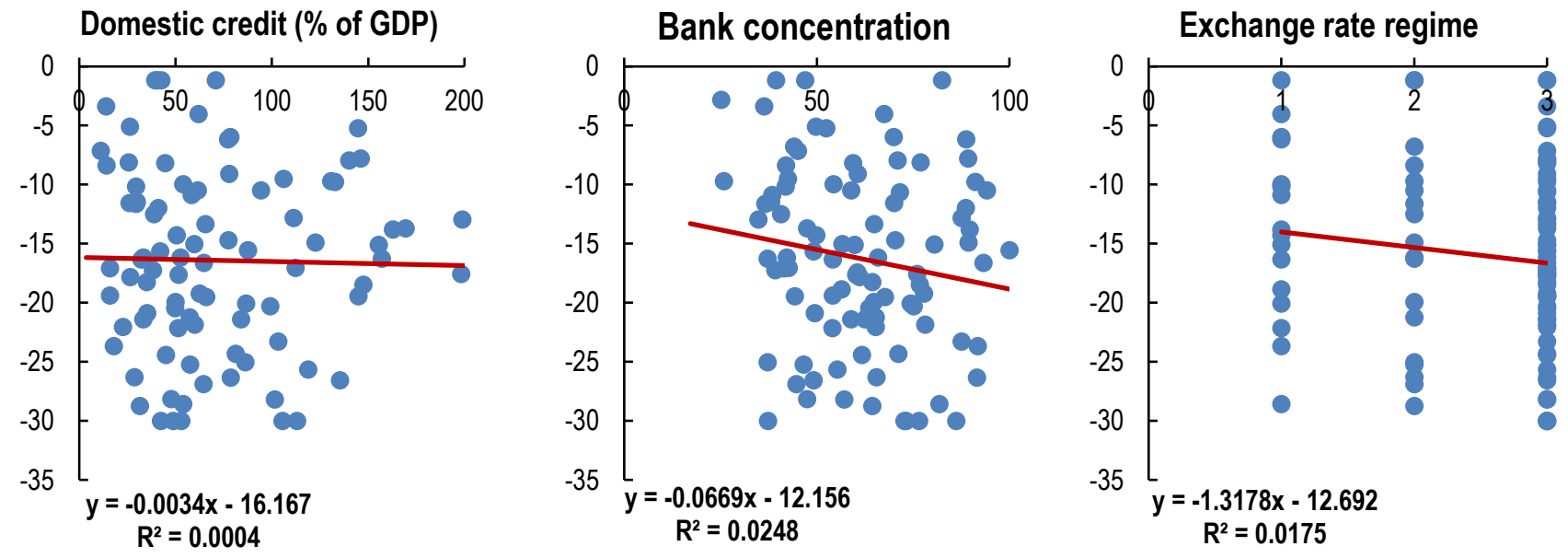

Note: Output performance is defined as the difference in cumulative real GDP growth between the first half of 2020 $(2020 \mathrm{H} 1)$ and the first half of $2019(2019 \mathrm{H} 1)$. 
Figure A6. Output performances (\%) and development, demographic and institutions

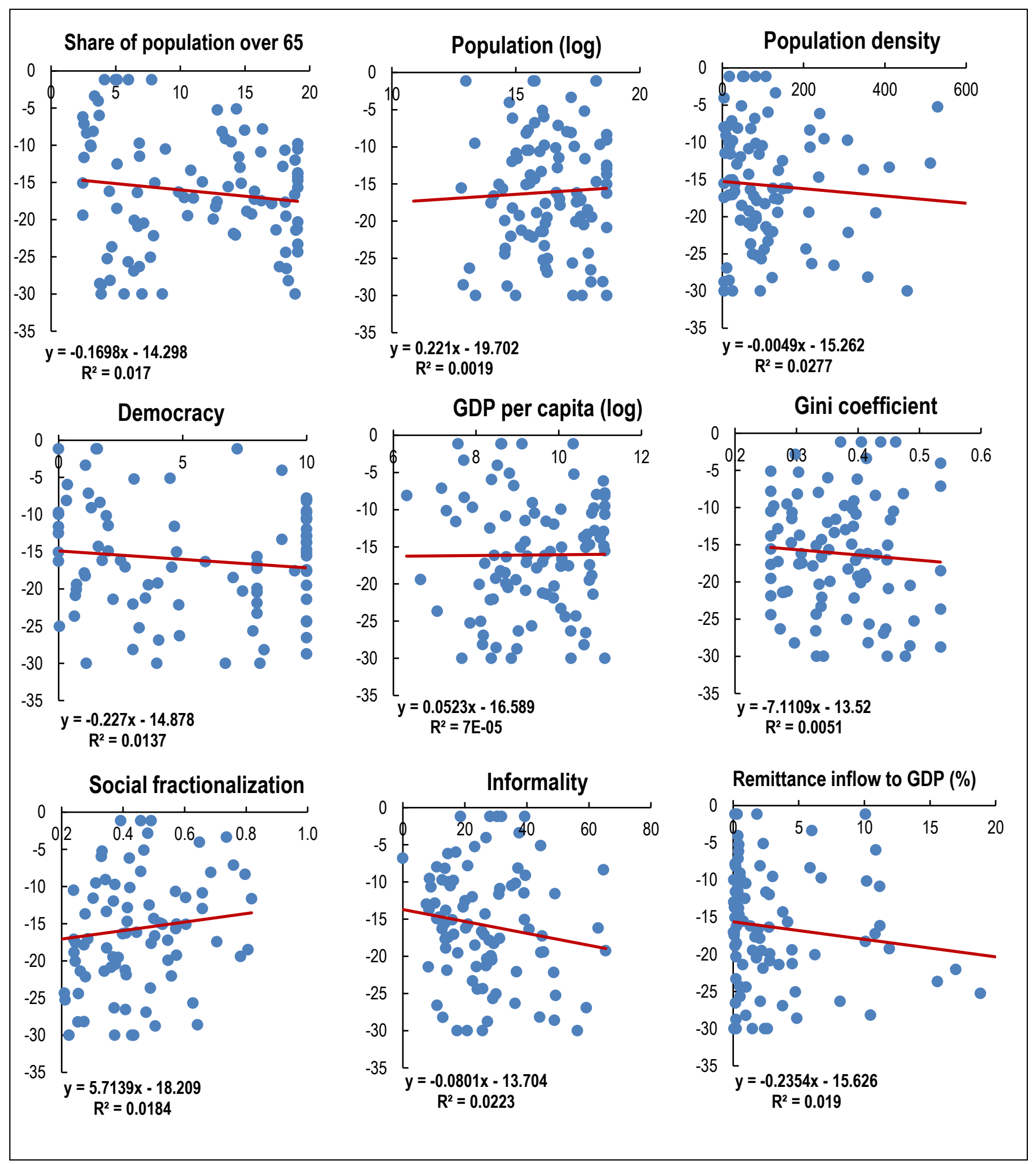

Note: Output performance is defined as the difference in cumulative real GDP growth between the first half of 2020 (2020H1) and the first half of 2019 (2019H1). 
Figure A7. Robust drivers of output performance across countries—controlling for outliers, magnitude of the effects

Panel A. Output performance 1

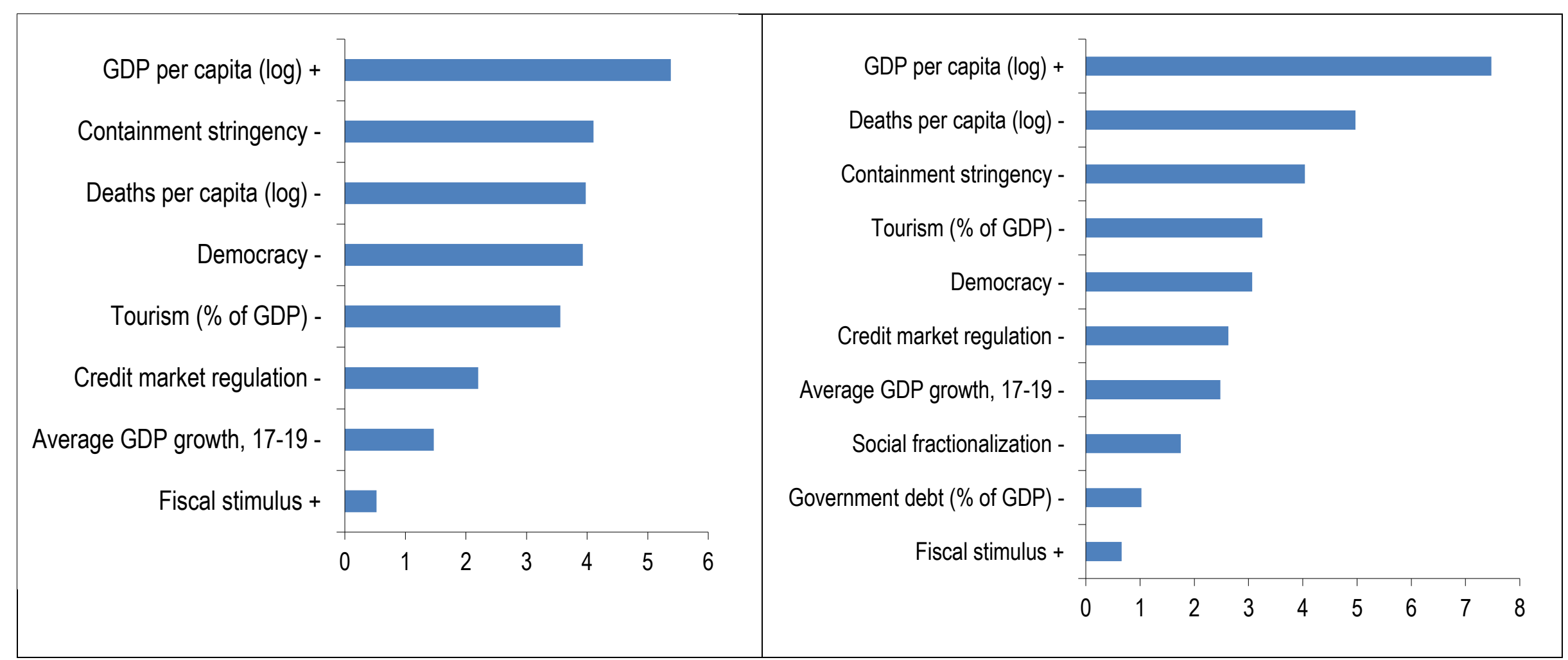

Note. Output performance 1 is the difference between the observed cumulative real GDP growth in $2020 \mathrm{H} 1$ and the cumulative growth that was expected before the onset of the pandemic for the same period-based on the IMF World Economic Outlook 2020 January forecast for 2020H1; Output performance 2 is the difference in cumulative real GDP growth between the first half of 2020 (2020H1) and the first half of 2019 (2019H1);. The chart shows the differential effect on output performance moving the level of the variable from the $25^{\text {th }}$ percentile to the $75^{\text {th }}$ percentile of its distribution, based on the coefficients of the variables that are robust in column (I-II) of Table 7. - (+) denotes a negative (positive) effect on output. Estimates based on equation (1). 
Figure A8. Robust drivers of output performance across countries—additional covariates, magnitude of the effects

Panel A. Output performance 1

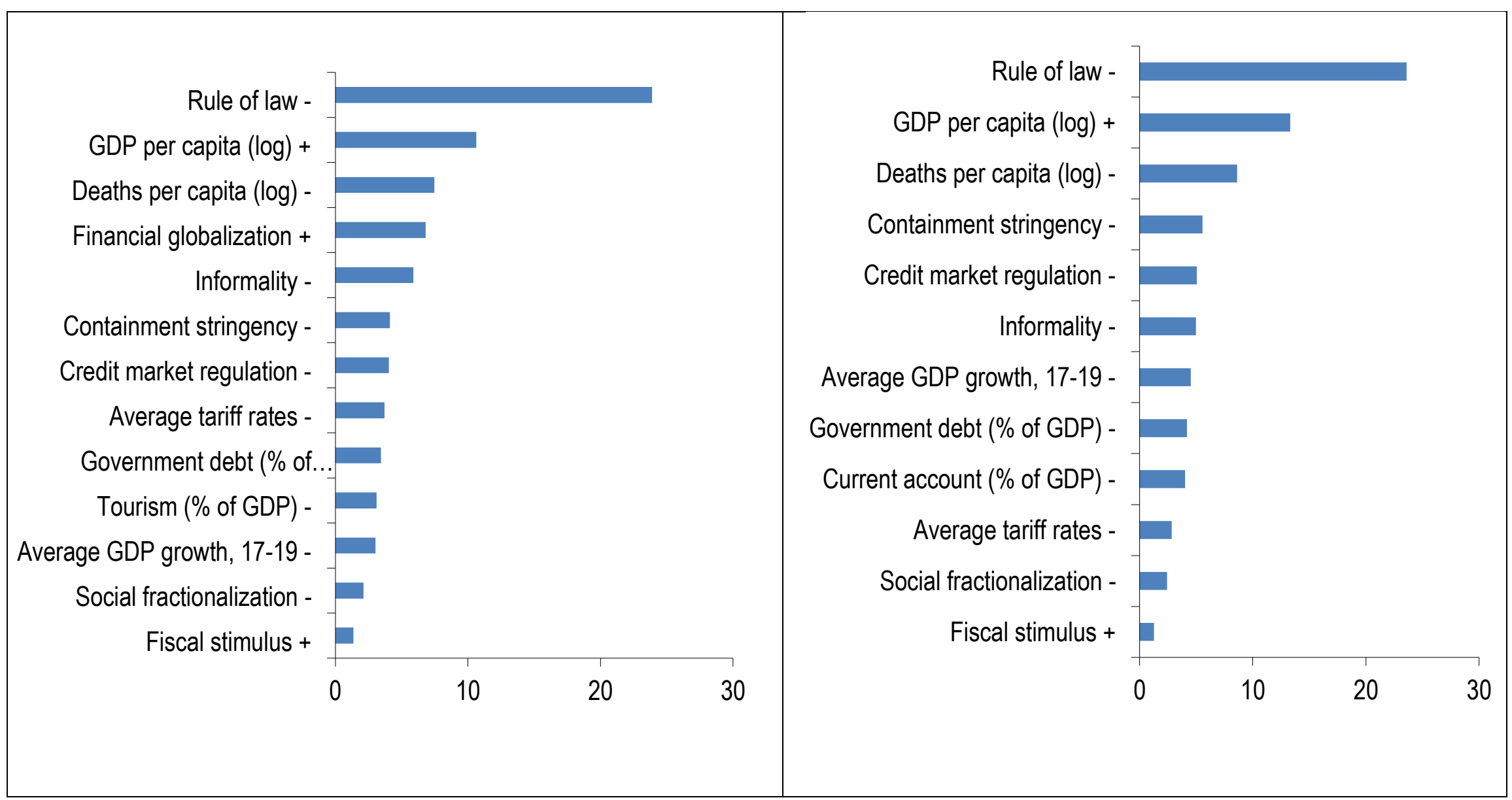

Note. Output performance 1 is the difference between the observed cumulative real GDP growth in 2020H1 and the cumulative growth that was expected before the onset of the pandemic for the same period — based on the IMF World Economic Outlook 2020 January forecast for 2020H1; Output performance 2 is the difference in cumulative real GDP growth between the first half of $2020(2020 \mathrm{H} 1)$ and the first half of 2019 (2019H1);. The chart shows the differential effect on output performance moving the level of the variable from the $25^{\text {th }}$ percentile to the $75^{\text {th }}$ percentile of its distribution, based on the coefficients of the variables that are robust in column (I-II) of Table 7. - (+) denotes a negative (positive) effect on output. Estimates based on equation (1). 
Figure A9. Robust drivers of output performance across countries—using Q2 deviation as dependent variable

Panel A. Output performance 1

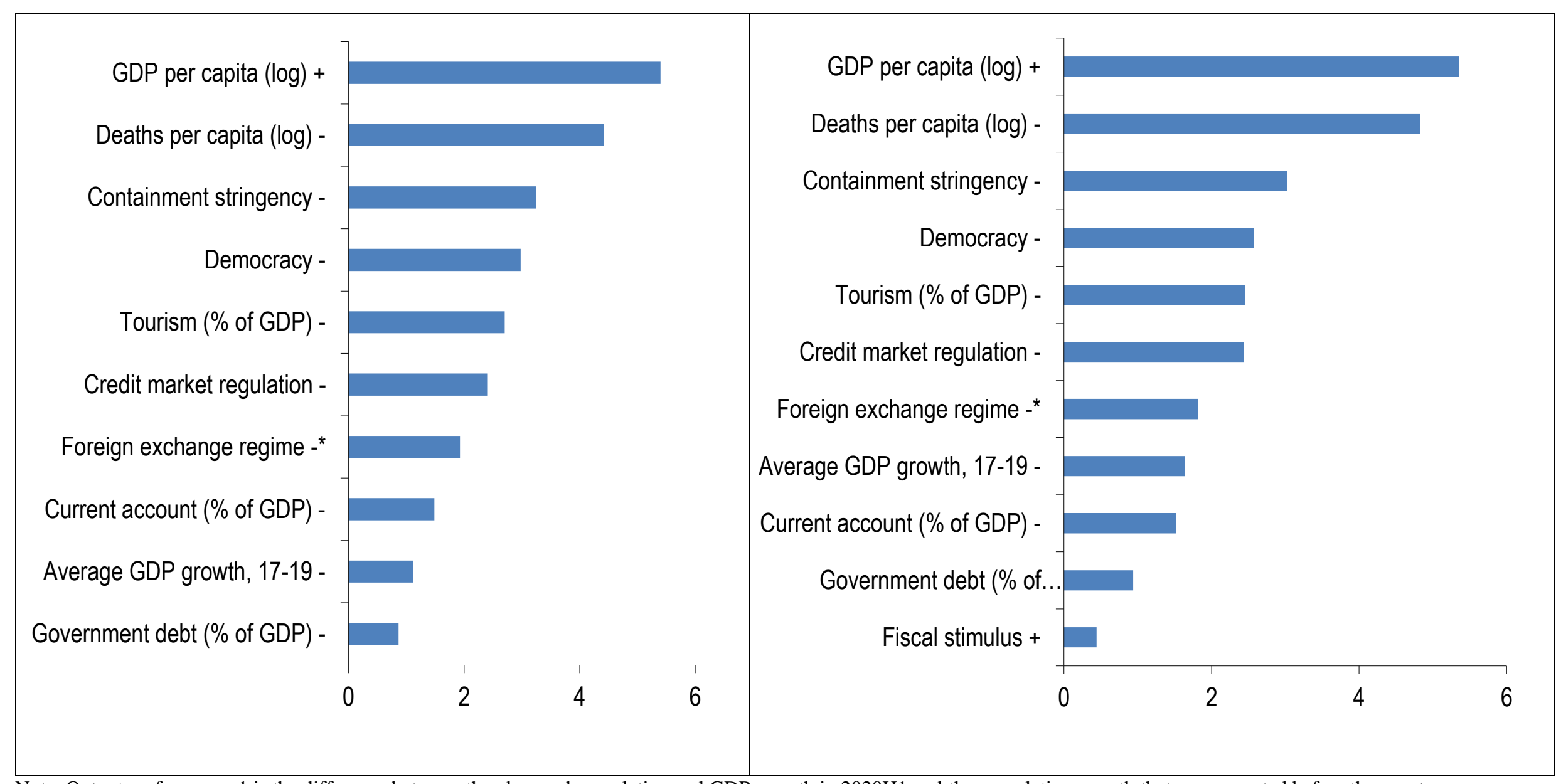

Note. Output performance 1 is the difference between the observed cumulative real GDP growth in 2020H1 and the cumulative growth that was expected before the onset of the pandemic for the same period — based on the IMF World Economic Outlook 2020 January forecast for 2020H1; Output performance 2 is the difference in cumulative real GDP growth between the first half of $2020(2020 \mathrm{H} 1)$ and the first half of $2019(2019 \mathrm{H} 1)$;. The chart shows the differential effect on output performance moving the level of the variable from the $25^{\text {th }}$ percentile to the $75^{\text {th }}$ percentile of its distribution, based on the coefficients of the variables that are robust in column (I-II) of Table 7. - (+) denotes a negative (positive) effect on output. Estimates based on equation (1). For foreign exchange regime, its interquartile value is 0 , instead we use the variation from the $10^{\text {th }}$ percentile to the $90^{\text {th }}$ percentile of its distribution.

Panel B. Output performance 2

(1)

(1)


Figure A10. Robust drivers of output performance across countries — interaction with income level (continuous), magnitude of the effects

Panel A. Output performance 1

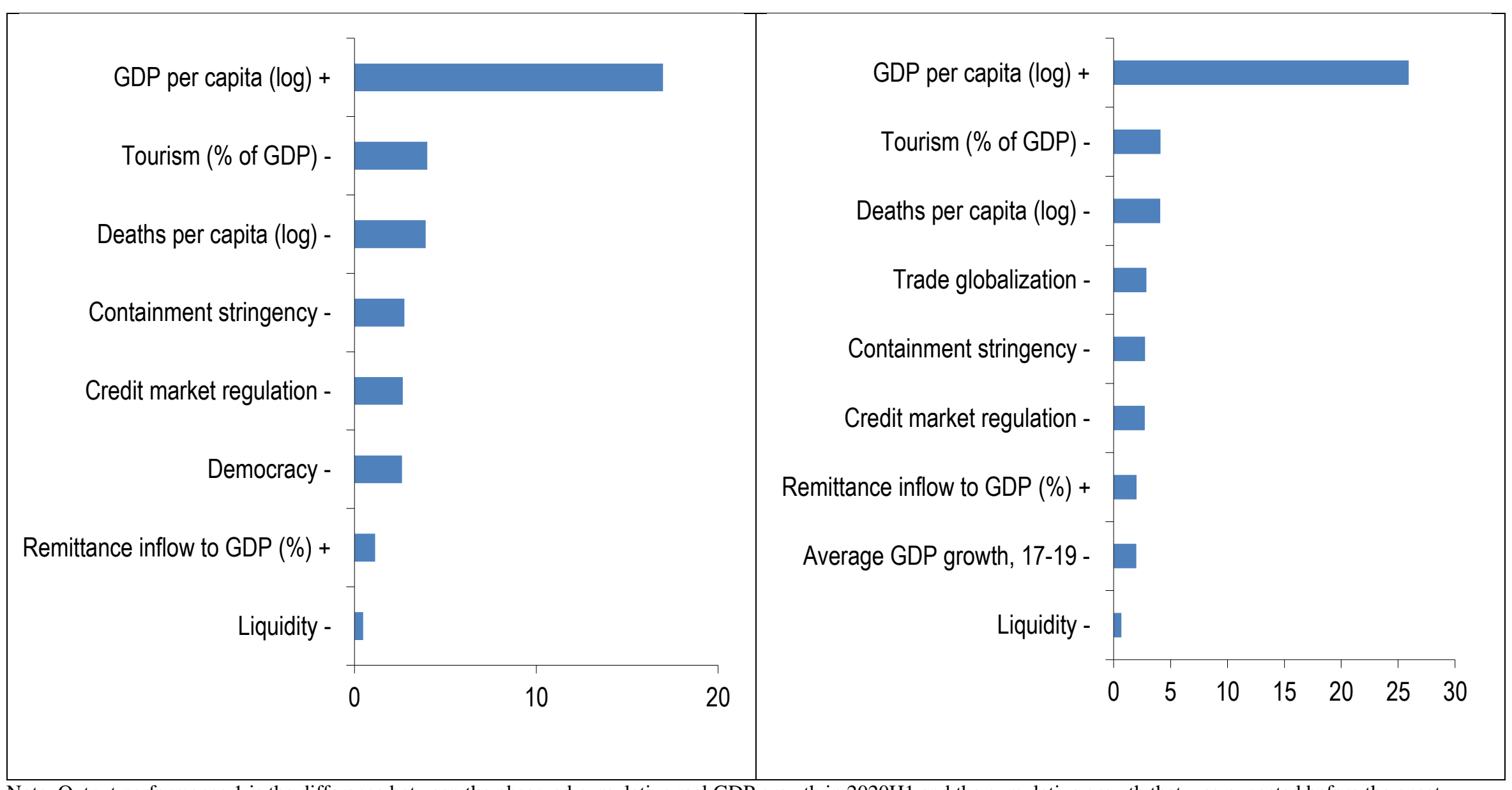

Note. Output performance 1 is the difference between the observed cumulative real GDP growth in 2020H1 and the cumulative growth that was expected before the onset of the pandemic for the same period - based on the IMF World Economic Outlook 2020 January forecast for 2020H1; Output performance 2 is the difference in cumulative real GDP growth between the first half of $2020(2020 \mathrm{H} 1)$ and the first half of 2019 (2019H1);. The chart shows the differential effect on output performance moving the level of the variable from the $25^{\text {th }}$ percentile to the $75^{\text {th }}$ percentile of its distribution, based on the coefficients of the variables that are robust in column (I-II) of Table 7. - (+) denotes a negative (positive) effect on output. Estimates based on equation (1).

Panel B. Output performance 2 
Figure A11. Robust drivers of output performance across countries - interaction with income level (dummy 1), magnitude of the effects

Panel A. Output performance 1

Panel B. Output performance 2

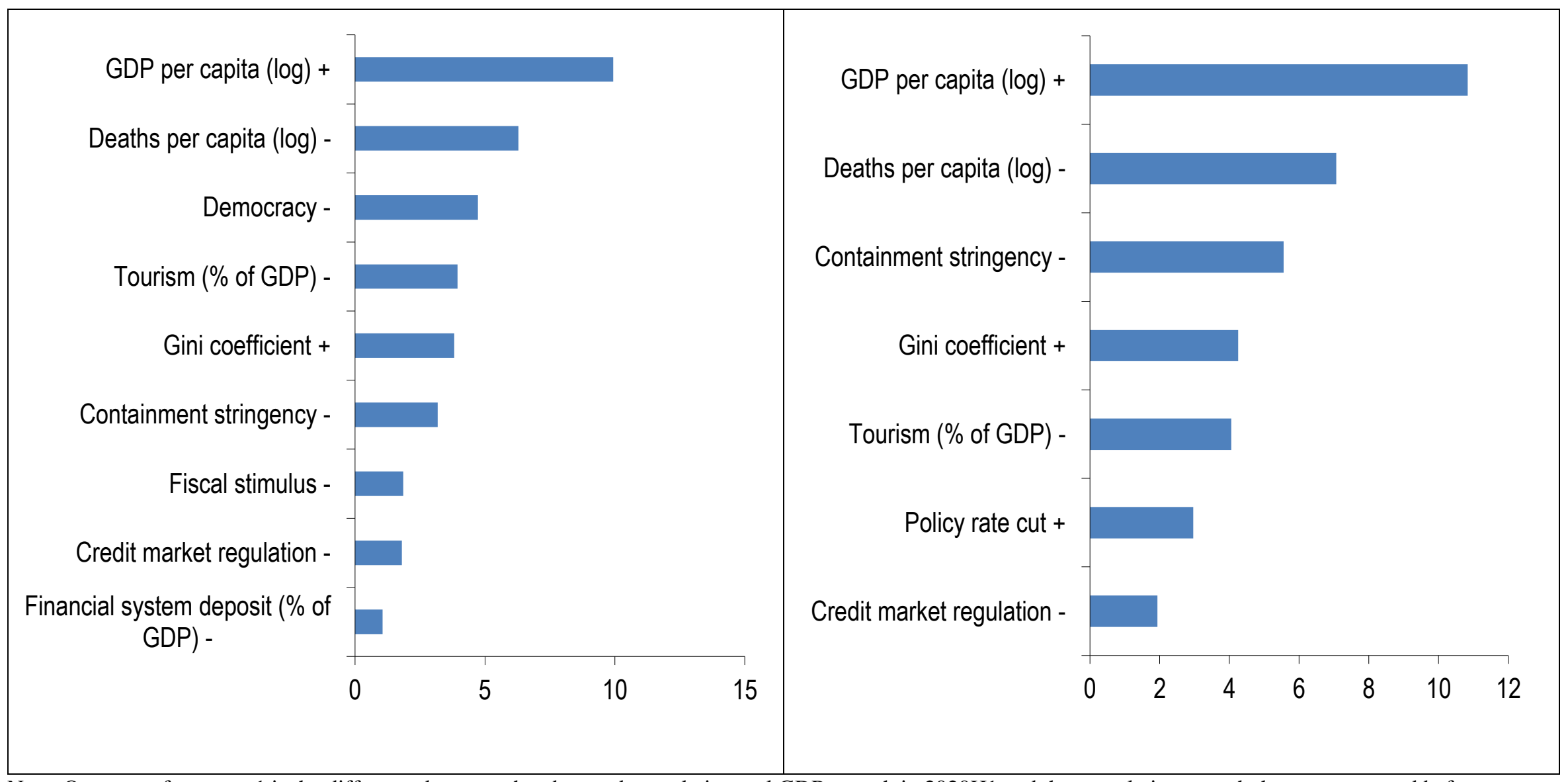

Note. Output performance 1 is the difference between the observed cumulative real GDP growth in 2020H1 and the cumulative growth that was expected before the onset of the pandemic for the same period - based on the IMF World Economic Outlook 2020 January forecast for 2020H1; Output performance 2 is the difference in cumulative real GDP growth between the first half of $2020(2020 \mathrm{H} 1)$ and the first half of $2019(2019 \mathrm{H} 1)$;. The chart shows the differential effect on output performance moving the level of the variable from the $25^{\text {th }}$ percentile to the $75^{\text {th }}$ percentile of its distribution, based on the coefficients of the variables that are robust in column (I-II) of Table 7. - (+) denotes a negative (positive) effect on output. Estimates based on equation (1). Dummy 1 uses the average of GDP per capita as reference, 1 denotes above average, otherwise 0 . 
Figure A12. Robust drivers of output performance across countries — interaction with income level (dummy 2), magnitude of the effects

Panel A. Output performance 1

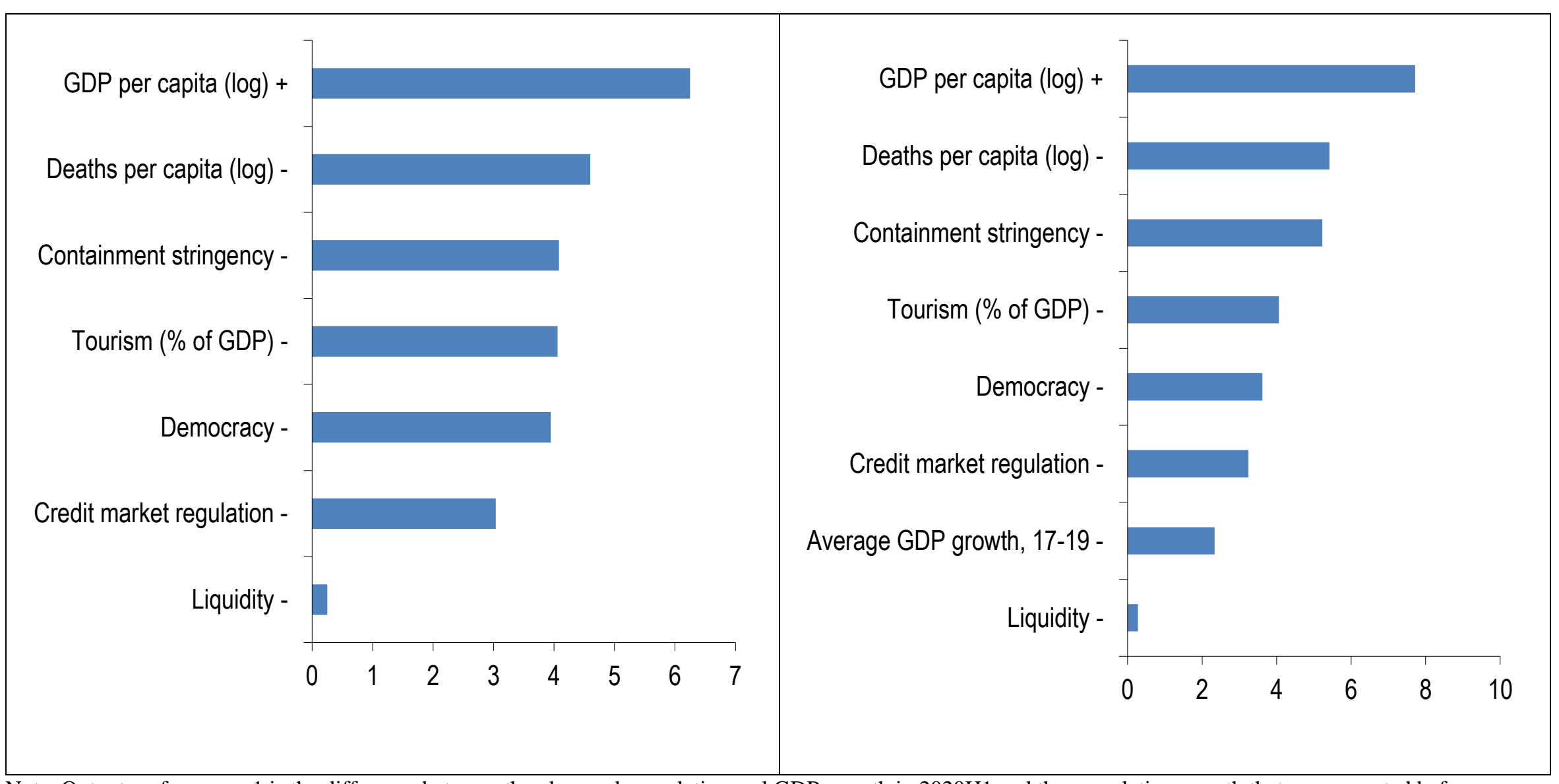

Note. Output performance 1 is the difference between the observed cumulative real GDP growth in 2020H1 and the cumulative growth that was expected before the onset of the pandemic for the same period — based on the IMF World Economic Outlook 2020 January forecast for 2020H1; Output performance 2 is the difference in cumulative real GDP growth between the first half of $2020(2020 \mathrm{H} 1)$ and the first half of $2019(2019 \mathrm{H} 1)$;. The chart shows the differential effect on output performance moving the level of the variable from the $25^{\text {th }}$ percentile to the $75^{\text {th }}$ percentile of its distribution, based on the coefficients of the variables that are robust in column (I-II) of Table 7. - (+) denotes a negative (positive) effect on output. Estimates based on equation (1). Dummy 2 uses the definition of income level in the World Economic Outlook, 1 is advanced economies, otherwise 0. 


\section{ANNEX B}

The objective of Model Averaging is to address model uncertainty by (i) running the maximum combination of possible models and (ii) providing estimates and inference results that take into account the performance of the variable not only in the final "reported" model but over the whole set of possible specifications. In practice, these two steps consist in estimating a parameter of interest conditional on each model in the model space and computing the unconditional estimate as a weighted average of conditional estimates. Formally, assuming that we are faced with $M$ different models and that $\beta^{x}$ is the coefficient related to the variable $X$, the final estimate of this coefficient is computed as:

$$
\hat{\beta}^{x}=\sum_{i=i}^{M} \omega_{i} \hat{\beta}_{i}^{x}
$$

where the weights $\omega_{i}$ denote a measure of goodness of fit of each model.

The Moving Averaging technique used in this paper is the Weighted Average Least Squares (WALS) proposed by Magnus, Powell, and Prüfer (2010) and generalized by De Luca and Magnus (2011) to introduce the distinction between focus and auxiliary regressors. Focus regressors are those that are forced to enter in each model based on priors guided by theory, while auxiliary regressors are those whose significance and model inclusion is tested. Given the lack of strong theoretical foundations on the drivers of COVID-19 output losses, we only consider the constant to be a focus regressor in the analysis.

Let's assume that the general statistical framework is a linear regression model of the form:

$$
y=X_{1} \beta_{1}+X_{2} \beta_{2}+\varepsilon
$$

where $y$ is vector of observations on the outcome of interest (output performance), $X_{1}$ is a matrix of observations and $k_{1}$ focus regressors, $X_{2}$ is a matrix of observations and $k_{2}$ auxiliary regressors, $\beta_{1}$ and $\beta_{2}$ their respective coefficients. Conditional on model $M_{i}$ being the true model, the sample likelihood function implied by B2 is $p\left(y \mid \beta_{1}, \beta_{2}, \sigma^{2}, M_{i}\right)$. Compared to the Bayesian Model Averaging (BMA) which uses a Gaussian distribution prior 
for the auxiliary parameters, the WALS uses a Laplace distribution which reduces the risk of the prior influencing heavily the final estimates (Magnus, Powell, and Prüfer 2010). The WALS relies on preliminary orthogonal transformation of the auxiliary regressors and their parameters. This consists of computing an orthogonal $k_{2} \times k_{2}$ matrix $\mathrm{P}$ and a diagonal $k_{2} \times k_{2}$ matrix $\Delta$ such that $P^{T} X_{2}^{T} M_{1} X_{2} P=\Delta$. The key advantage of this transformation is that the space over which model selection is performed increases linearly rather than exponentially in size (as in the BMA).

Denoting $\bar{t}$ the Laplace estimator of the vector of theoretical t-ratios of the auxiliary regressors $\left(t=\left[t_{1}, t_{2}, \ldots t_{k 2}\right]\right)$, the WALS estimators of the coefficients $\beta_{1}$ and $\beta_{2}$, are given respectively by:

$$
\begin{aligned}
& \widehat{\beta_{1}}=\left(X_{1}^{T} X_{1}\right)^{-1} X_{1}^{T}\left(y-X_{2} \widehat{\beta_{2}}\right) \\
& \hat{\beta}_{2}=s P \Delta^{-1 / 2} \bar{t}
\end{aligned}
$$

To decide whether a given auxiliary regressor is a robust determinant of the outcome of interest, Magnus, Powell, and Prüfer (2010) suggest an absolute value of the t-ratio greater than 1 for a variable to qualify as robust. This choice is motivated by the fact that including a given auxiliary regressor variable increases the model fit (as measured by the adjusted $R^{2}$ ) and the precision of the estimators of focus regressors (measured by a lower MSE) if and only if the t-ratio of the additional auxiliary regressor is in absolute value greater than 1. 